\title{
The I mpact of Training on Productivity and Wages: Firm Level Evidence
}

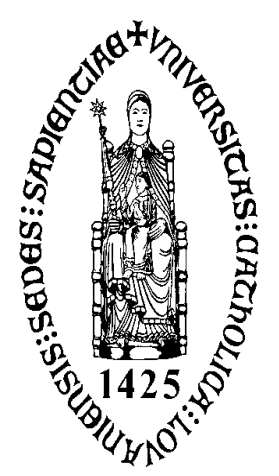

\section{Katholieke Universiteit Leuven}

LICOS Centre for Institutions and Economic Performance Huis De Dorlodot

Deberiotstraat 34 - mailbox 3511

B-3000 Leuven

BELGIUM

TEL:+32-(0)16326598

FAX:+32-(0)163265 99

http://www.econ.kuleuven.be/licos 


\title{
The Impact of Training on Productivity and Wages: Firm Level Evidence*
}

\author{
Jozef Konings ${ }^{\dagger}$ and Stijn Vanormelingen ${ }^{\ddagger}$
}

August 31, 2009

\begin{abstract}
This paper uses firm level panel data of firm provided training to estimate its impact on productivity and wages. To this end the strategy proposed by Ackerberg, Caves and Frazer (2006) for estimating production functions to control for the endogeneity of input factors and training is applied. The productivity premium for a trained worker is estimated at $23 \%$, while the wage premium of training is estimated at $12 \%$. Our results give support to recent theories that explain work related training by imperfect competition in the labor market.
\end{abstract}

JEL codes: J24, J31, L22

Keywords: Training, production functions, human capital.

\footnotetext{
${ }^{*}$ We would like to thank Bart Cockx, Marton Csillag, Jan De Loecker, Steve Pischke, Bee Roberts and Vitor Gaspar for useful comments and suggestions. This paper has benefited from presentations at the Belgian Day for Labour Economists in Louvain-la-Neuve, the HU Brussel Research Seminar Series and the Panel Data Conference in Bonn.

${ }^{\dagger} \mathrm{KU}$ Leuven and BEPA, European Commission

${ }^{\ddagger} \mathrm{HU}$ Brussel and LICOS, KU Leuven
} 


\section{Introduction}

In recent years trade unions, employers and policy makers have emphasized the importance of skill upgrading of workers and life long learning in order to cope with increased pressures induced by technological change and globalization (e.g; European Commission, 2007). While there exists a large literature showing that the accumulation of human capital through the general education system plays a crucial role in explaining long run income differences between rich and poor countries, much less work exists on the effects of training provided by firms, often requiring specific skills from their workers.

In his seminal work, Becker(1964) made a distinction between firm specific and general training. General training results in skills that are equally applicable at other firms while skills acquired through firm specific training are lost when the trained worker leaves the firm that provided training. Under perfect competition in the labor market, workers should pay for costs of general training and recoup these costs by earning higher wagers. When training is specific, firms pay (part of) the training costs ${ }^{1}$. However, Acemoglu and Pischke (1999a, 1999b) point out that in numberous cases firms provide and pay for training that is general in nature. They show how this can be explained by labor market imperfections. In particular, a necessary condition for firms to pay for general training is that wages increase less steeply in training than productivity. This is referred to as a compressed wage structure which can be caused by frictions in the labor market such as search costs, informational asymmetries, efficiency wages and labor market institutions such as unions or the presence of minimum wage laws. With a compressed wage structure, training increases the marginal product of labor more than wages, which creates incentives for the firm to invest in training.

While there exists substantial evidence that general education increases wages $^{2}$ and productivity of workers, there is hardly any work that studies the impact of work related training on firm level productivity and wages. Moretti

\footnotetext{
${ }^{1}$ In fact, with firm specific training it is more efficient if firms and workers share the costs and benefits of training. Wages of workers increase after specific training above the level they could earn elsewhere but lower than their marginal product which reduces both the probability they quit the firm and the propability they are laid off.

${ }^{2}$ Card (1999), for instance, summarizes various studies and concludes that the impact of a year of schooling on wages is about $10 \%$.
} 
(2004) focuses on plant level productivity gains from education, but he has no data on firm provided training. He finds that plants operating in cities that experience a large increase in the share of college graduates have higher productivity gains than in cities that have a lower increase in college graduates, but these productivity gains are offset by wage increases. Bartel (1995) studies how firm provided training affects wage profiles of workers and job performance scores in one large firm and finds that training has a positive effect. Dearden, Reed and Van Reenen (2006) analyze the link between training, wages and productivity at the sector level using a panel of British industries. They find that raising the proportion of workers in an industry who receive training by one percentage point increases value added per worker in the industry by $0.6 \%$ and average wages by $0.3 \%$.

Our paper makes several contributions to the literature. First, we make use of firm level data about training. Belgian firms are obliged by law to submit a supplement to the annual report which contains information on various elements of training, such as the proportion of workers that received training, the number of hours they were trained and the cost of training to the firm. This data allows us to measure the impact of training on both wages and productivity at the firm level and we can infer whether trained workers are paid the value of their marginal product. By focusing on firm level data we are able to avoid possible aggregation biases and hence capture the effects of training more precisely. Second, the analysis at the firm level allows us to control for the endogeneity of training. To this end we use the estimation strategy recently introduced by Ackerberg, Caves and Frazer (2006) for estimating production functions which allows us to control for the endogeneity of input factors. Third, we are able to explore various dimensions of the data set. Because of the large number of observations, we can analyze differences between narrowly defined sectors with respect to the impact of training on firm performance and we are able to measure differential impacts on wages and productivity for male versus female workers.

Our main findings can be summarized as follows. Training has a positive impact on productivity and wages. The marginal product of a trained worker is on average $23 \%$ higher than that of an untrained worker while wages only increase with $12 \%$ in response to training. This finding is consistent with recent theories that explain firm provided training by models with imperfect competition in the 
labor market and is robust against different kinds of specifications and estimation strategies. Among the different manufacturing sectors, largest productivity gains can be found in the Chemicals and Rubber \& Plastic industries. Finally we find that there is no differential impact of training on the productivity of male versus female workers, but wages increase more in response to training for female workers than for male workers.

The next section gives the empirical framework we use and we describe our estimation strategy in Section 3. We give an overview of the dataset in Section 4. Results are reported in Section 5 and we conclude in Section 6.

\section{Empirical Framework}

We infer the impact of training on both wages and productivity by applying a framework used by Hellerstein et al. (1999). The idea is to simultaneously estimate a wage equation and a production function to compare gains in wages with the gains in productivity that may arise in response to training. In competitive labor markets, returns from human capital formation accrue to workers in the form of wages and the productivity premium of a trained worker equals its wage premium ${ }^{3}$.

\subsection{Impact of training on productivity}

The output of a firm $i$ in period $t$ is a function of capital and a quality labor aggregate used by the firm in period $t$. As is common in the literature, we assume that this function takes the Cobb-Douglas form:

$$
Y_{i t}=A_{i t} \widehat{L}_{i t}^{\beta_{l}} K_{i t}^{\beta_{k}}
$$

with $Y_{i t}$ value added, $\widehat{L}_{i t}$ the quality of labor aggregate and $K_{i t}$ is capital of firm $i$ in period $t$. $A_{i t}$ represents Hicks neutral technical efficiency of the firm. Taking

\footnotetext{
${ }^{3}$ The framework has been applied among others by Jones (2001) to examine the impact of education on earnings and productivity and by Hellerstein and Neumark (1999) to estimate whether the wage gap between men and women can be explained by productivity differentials. Frazer (2001) uses the methodology to find unbiased estimates for the impact of education on wages. More recently Van Biesebroeck (2007) applies the framework to estimate returns to human capital on both productivity and wages for some African countries and Dearden et al. (2006) estimate the impact of training on wages and productivity for a panel of UK industries.
} 
natural logarithmes of all variables, the logarithm of output can be written as linear function of the logarithm of inputs ${ }^{4}$ :

$$
y_{i t}=\beta_{0}+\beta_{l} \widehat{l}_{i t}+\beta_{k} k_{i t}+\mu_{i t}
$$

where $l$ is the labor aggregate, $k$ is capital and $y$ is value added of firm $i$ in period $t$. The productivity term $a_{i t}$ can be decomposed in a fixed component $\beta_{0}$ which is common to all firms and a component $\mu_{i t}$ which represents firm and time specific deviations from the average productivity level.

So far, the assumption of the homogeneity of labor has been maintained. Now we relax this assumption and take into account the amount of training that is provided by each firm to its employees. There are several ways to bring training into the model. First, we define training as a discrete characteristic, namely we divide the labor force into trained and untrained workers. Second, we take into account the intensity of training and use training costs as a variable to reflect differences between employees.

If we model training as a discrete characteristic, the labor aggregate $\widehat{L}$ can be written as the sum of the number of each type of worker multiplied with its marginal productivity level relative to that of an untrained worker ${ }^{5}$. The relative (marginal) productivity differential of a trained worker compared to an untrained worker, $\phi_{T}$, is defined as $\phi_{T} \equiv \frac{\partial Y / \partial L_{T}-\partial Y / \partial L_{U}}{\partial Y / \partial L_{U}} \equiv \frac{M P_{T}-M P_{U}}{M P_{U}}$ where $L_{U}$ and $L_{T}$ represent respectively the number of untrained and trained workers. We can then write the labor aggregate $\widehat{L}$ as

$$
\widehat{L}=L_{U}+\left(1+\phi_{T}\right) L_{T}
$$

This functional form assumes that trained and untrained workers are perfect substitutes and a firm makes its training decisions solely based on productivity differences between employees and the cost of training. We can rewrite $\widehat{L}$ as:

$$
\widehat{L}=L\left(1+\phi_{T} \frac{L_{T}}{L}\right)
$$

Here $L$ represents the total number of employees and is by definition the sum of both trained and untrained workers. Consequently, $\frac{L_{T}}{L}$ is the fraction of trained workers in the labor force. Substituting Equation (4) in Equation (2) gives:

\footnotetext{
${ }^{4}$ Throughout the rest of the paper, lower case letters represent variables expressed in logarithms.

${ }^{5}$ Firm and time subscripts are omitted for the rest of this section. When we turn to the estimation strategy in the next section, we will reintroduce the subscripts.
} 


$$
y=\beta_{0}+\beta_{l} l+\beta_{l} \ln \left(1+\phi_{T} \frac{L_{T}}{L}\right)+\beta_{k} k+\mu
$$

or when $\phi_{T} \frac{L_{T}}{L}$ is small, this can be approximated by

$$
y=\beta_{0}+\beta_{l} l+\beta_{l} \phi_{T} \frac{L_{T}}{L}+\beta_{k} k+\mu
$$

In principle we can infer the training premium from a linear regression of output on capital, labor and the share of trained workers in total employment. For example if we estimate $\phi_{T}$ to be .20 , this implies that the marginal product of a trained worker is $20 \%$ higher than that of an untrained worker ${ }^{6}$. However both inputs and the number of trained workers are likely to be correlated with elements of the unobserved productivity $\mu$ of a firm which complicates the identification of the coefficients. We turn back to this issue in Section 3. In Appendix A we generalize the approach to include multiple characteristics of the workforce.

So far we have defined training as a discrete characteristic. Either a worker has received training over the period or he has not. However, this is a simplification since there exists considerable variation in the amount of training each worker received. For example, the firm specific average investment in training per worker trained ranges from less than $100 €$ to more than $10,000 €$. To take into account these variations in training intensity across trained workers, we include training as a continuous variable instead of a binary variable. Frazer (2001) shows how to derive the labor aggregate in a production function consistent with Mincer (1974) when the characteristic that differentiates the labor force is a continuous variable ${ }^{7}$. In our baseline model, workers differ only by the amount of training they received. A typical equation in the style of Mincer (1974) that explains the earnings of individual $j$ as a function of the amount of training he obtained, looks like:

$$
\ln \left(W_{j}\right)=\alpha_{0}+\alpha_{T} T_{j}+\nu_{j}
$$

${ }^{6}$ Note that to measure the impact of training on output, $\phi_{T}$ has to be multiplied by the labor coefficient: $\frac{\partial \ln Y}{\partial L_{T}}=\phi_{T} \beta_{l}$.

${ }^{7}$ To be precise, Frazer (2001) derives this result under the assumption of perfect competition in the labor market. Intuitively, if a firm is profit maximizing and acts as a price taker in the labor market, differences in wages should reflect differences in marginal products and the aggregate labor term in the production function should have exactly the same functional form as the wage equation. However, with for example labor market frictions, productivity premia do not necessarily equal wage premia and we have to assume that the functional form of the labor aggregate in the production function is the same as the functional form of the wage equation. 
which means that the average wage bill of a firm can be written as $\sum_{j} \exp \left(\alpha_{0}+\right.$ $\left.\alpha_{T} T_{j}+\nu_{j}\right)$. Here $T_{j}$ represents the amount of training worker $j$ has received. Frazer (2001) proves that if the firm is maximizing its profits, the labor term in the production function should have the same form as the wage bill, i.e. $\widehat{L}=\sum_{j} \exp \left(\beta_{1}+\beta_{T} T_{j}\right)$ and the production function can be written as follows:

$$
Y=A\left(\sum_{j} \exp \left(\beta_{1}+\beta_{T} T_{j}\right)\right)^{\beta_{l}} K^{\beta_{k}}
$$

where $\beta_{T}$ measures how the contribution of an individual worker $j$ to the aggregate labor term varies with the amount of training he received $\left(\partial \ln (\widehat{L}) / \partial T_{j}=\right.$ $\left.\beta_{T}\right)$. Taking natural logrithmes, this can be rewritten as:

$$
y=\beta_{l} \beta_{1}+\beta_{l} \ln \left(\sum_{j} \exp \left(\beta_{T} T_{j}\right)\right)+\beta_{k} k+a
$$

A first-order Taylor approximation of the labor term results in a loglinear equation that can be estimated (cf. Frazer, 2001). The logarithm of output is a function of the logarithm of the number of workers and capital and the average training intensity of all workers in a particular firm:

$$
y=\beta_{0}^{*}+\beta_{l} l+\beta_{l} \beta_{T} \bar{T}+\beta_{k} k+\mu
$$

The coefficient on average training intensity $\beta_{T}$ measures how the labor aggregate changes with training intensity. The impact of training on output depends also on the importance of labor in the production function $\beta_{l}$, i.e. $\partial y / \partial T=\beta_{l} \beta_{T}$, which represents the percentage changes in output in response to variations in average training intensity of the workforce.

\subsection{Impact of training on wages}

We derive wage equations similar to Equations (6) and (10). The wage equation will be more descriptive than the structural productivity equation. Again, we first build up the empirical framework defining training to be a discrete characteristic. Second, we take into account the variations in training intensity in terms of training costs accross trained employees.

To measure wage differentials between trained and untrained employees, we apply firm-level wage equations as in Hellerstein et al. (1999). We define a wage equation in the style of Mincer (1974) for individual $j$ :

$$
W_{j}=W_{U} D_{j, U}+W_{T} D_{j, T}
$$


where $W_{j}$ is the wage of individual $j . W_{U}$ and $W_{T}$ are the average wages of an untrained and trained employee respectively and $D_{j, U}$ and $D_{j, T}$ represent a dummy eaqual to one if the employee received no training or training. By summing over all employees at a firm, the total wage bill of a firm equals the sum of the wages of trained and untrained employees multiplied by respectively the number of trained and untrained employees active in the firm. This expression can be rewritten as

$$
\bar{W} L=W_{U} L_{U}+W_{T} L_{T}=W_{U} L+\lambda_{T} W_{U} L_{T}=W_{U} L\left(1+\lambda_{T} \frac{L_{T}}{L}\right)
$$

where $\lambda_{T}=\frac{W_{T}-W_{U}}{W_{U}}$ represents the relative wage premium for a trained employee compared to an untrained one. Dividing both sides by the number of employees and taking logs of Equation (11) one obtains

$$
\begin{aligned}
\bar{w} & =w_{U}+\ln \left(1+\lambda_{T} \frac{L_{T}}{L}\right) \\
& \approx w_{U}+\lambda_{T} \frac{L_{T}}{L}
\end{aligned}
$$

Where the last step follows from the fact that $\ln (1+x)$ can be approximated by $x$ if $x$ is small. This equation at the firm level is consistent with the individual level Mincer (1974) wage equations. Under perfect competition on the labor market, wages do not vary systematically across firms and regressing the average wage on a constant and the share of trained employees will give a consistent estimate for the relative wage premium of trained employees. However, we will include the capital intensity and total factor productivity in the estimation equation in order to allow for imperfectly competitive labor markets and unobserved differences in labor quality which should be reflected in total factor productivity. Adding a vector of control variables $X$ and an additive error term ${ }^{8}$ to equation (12) we get:

$$
w=w_{U}+\lambda_{T} \frac{L_{T}}{L}+X \gamma+\varepsilon
$$

which can be estimated by applying a least squares estimator ${ }^{9}$.

The derivation of a firm level wage equation when we take into account variations in training intensity accross trained workers is similar to the derivation

\footnotetext{
${ }^{8}$ Note that Equation (12) is not a behavioral equation, but simply defines the average wage to be a function of the wages of each different type of worker. The error term that we add can represent measurement error, variation across firms in wages across firms unrelated to productivity differences, regional differences in labor market conditions, ... .

${ }^{9}$ Again, we refer to Appendix A for the inclusion of multiple workforce characteristics in the wage equation.
} 
of the labor aggregate in the production function of the previous section. The average wage in a firm can be written as:

$$
\bar{w}=w_{U}+\alpha_{T} \bar{T}
$$

Where $\bar{T}$ represents average training costs per employee, $\alpha_{T}$ measures how wage premiums change with the intensity of training $(\partial w / \partial T)$ and $w_{U}$ is the average wage of a worker that received no training at all. Again we add an additive error term and control variables:

$$
\bar{w}=w_{U}+\alpha_{T} \bar{T}+X \gamma+\varepsilon
$$

which can be estimated using ordinary least squares.

\section{Estimation strategy}

One needs to be careful in estimating the production function in Equation (2) since inputs are likely to be correlated with the unobserved productivity term. In this section, we describe in detail how we solve this problem. Recall the production function derived in the previous section:

$$
y_{i t}=\beta_{0}+\beta_{l} l_{i t}+\beta_{l} \phi_{T} \frac{L_{T, i t}}{L_{i t}}+\beta_{k} k_{i t}+\omega_{i t}+\eta_{i t}
$$

where the unobserved productivity term $\mu_{i t}$ is divided into two components, namely $\omega_{i t}$ and $\eta_{i t}$. Unobservables that are not seen by the firm at the moment when it makes its input decisions are represented by the mean zero error term $\eta_{i t}$. Consequently, inputs will be uncorrelated with this unobservable. An example is an unexpected machine breakdown or strike. Also measurement error in the output variable can be incorporated in $\eta_{i t}$. The $\omega_{i t}$ represents productivity unobserved by the econometrician, but observed by the firm before making its input decisions. Examples include managerial ability, expected machine breakdowns, technological progress, worker ability,... As such the input choices are likely to be correlated with the unobserved error term $\omega_{i t}$ and estimating Equation (16) with OLS will generate biased coefficient estimates. This simultaneity bias has been documented first by Marschak and Andrews $(1944)^{10}$. Note that also the unobserved (by the econometrician) ability of employees or labor quality is likely to be included in the productivity term $\omega_{i t}$. If firms tend to provide

\footnotetext{
${ }^{10}$ For an overview of the outstanding issues in estimating production functions, we refer to Ackerberg et al. (2005).
} 
training to the most able employees, for example because they are faster learners and therefore require a smaller training investment, the estimated coefficient on the training variable will be upward biased.

Olley and Pakes (1996) offer a solution to the endogeneity problem. They set up a dynamic model and derive the productivity $\omega_{i t}$ to be a function of investment and capital. As such, productivity can be proxied by a nonparametric function of investment and capital and can be controlled for in the estimation of Equation (16). The drawback of this method is that only observations with positive investment levels can be used in the estimation. Levinsohn and Petrin (2003) overcome this problem by using material inputs instead of investment in the estimation of productivity $\omega_{i t}$. Both methods assume that labor has no dynamic implications and hence the choice of labor in year $t$ has no impact on future profits. This implies among others that there can be no hiring and firing costs and that firms can choose each period the optimal amount of labor at a given wage rate without any limitations. Given that Belgium is a highly unionized country with a rigid labor market and that there exist considerable costs in laying off employees, we will relax this assumption. Moreover, Ackerberg, Caves and Frazer (2006) note that identifying the coefficients on labor and materials using the Levinsohn and Petrin (2003) or Olley and Pakes (1996) methodology could be problematic due to collinearity issues. For these reasons, we will follow the methodology proposed by Ackerberg, Caves and Frazer (2006) to correct for the simultaneity bias, which we will discuss now in more detail.

We keep the timing assumption made in Levinsohn and Petrin (2003) and Olley and Pakes (1996) about the capital accumulation function:

$$
k_{i t}=(1-\delta) k_{i t-1}+i_{i t-1}
$$

with $i_{i t-1}$ investment decided in period $t-1$. Intuitively, the expression means that it takes a full period to order and install the new capital goods before they enter the production process. We will use this assumption to identify the capital coefficient in the second stage of the estimaton strategy since by definition the capital stock will be uncorrelated with the part of productivity in year $t$, unforeseen in year $t-1$. Furthermore we assume that $\omega_{i t}$ follows a first-order Markov process:

$$
p\left(\omega_{i t} \mid I_{i t-1}\right)=p\left(\omega_{i t} \mid \omega_{i t-1}\right)
$$


where $I_{i t}$ is the information set of firm $i$ at period $t-1$. This assumption means that firms' expectations of future productivity only depend on current productivity. We assume material input to be chosen after labor input and training which seems plausible for an economy with rigid labor markets like Belgium. As a result, material demand will not only be a function of capital and productivity (as in Levinsohn and Petrin 2003), but also of labor and training:

$$
m_{i t}=f_{t}\left(\omega_{i t}, l_{i t}, \frac{L_{T, i t}}{L_{i t}}, k_{i t}\right)
$$

When this material demand function is strictly increasing in productivity $\omega_{i t}$, it can be inverted to obtain an expression for productivity $\omega_{i t}=$ $f_{t}^{-1}\left(m_{i t}, l_{i t}, \frac{L_{T, i t}}{L_{i t}}, k_{i t}\right)$. Note that we have to assume that productivity is the only unobservable in the material demand function. This means that input prices are constant across firms ${ }^{11}$ and there are no other unobservables affecting material demand but not production. An important advantage of this procedure is that the setting allows labor and training to have dynamic implications such that the optimal choice of training, $l_{i t}$ and $k_{i t}$ depend on previous labor, training and capital input decisions ${ }^{12}$. Obviously, the optimal choice of material input does not depend on previous choices of capital, labor and training. Material input in period $t$ has only an impact on profits in period $t$ and thus depends only on the other inputs in year $t$. Substituting inverse material demand in the production function gives the first stage equation ${ }^{13}$ :

$$
y_{i t}=\beta_{l} l_{i t}+\beta_{t r} \frac{L_{T, i t}}{L_{i t}}+\beta_{k} k_{i t}+f_{t}^{-1}\left(m_{i t}, l_{i t}, \frac{L_{T, i t}}{L_{i t}}, k_{i t}\right)+\eta_{i t}
$$

We will use a series estimator with a polynomial in materials, labor, capital and training to proxy the inverse demand function $f^{-1}($.$) . Clearly \beta_{l}, \beta_{k}$, and $\beta_{t r}$ will not be identified here since these inputs are also included in the inverse material demand function. This is in contrast with Olley and Pakes (1996) and Levinsohn and Petrin (2003) who identify the labor coefficient in the first stage

\footnotetext{
${ }^{11}$ We include year dummies to control for input prices changing over time.

${ }^{12}$ As noted by Ackerberg, Caves and Frazer (2006), another advantage of this procedure is that it is consistent with other unobservables affecting firm's choices of $l_{i t}, k_{i t}$ and $L_{i T}$. This is because $m_{i t}$ depends directly on $l_{i t}, k_{i t}$ and $L_{i T}$. These unobservables, such as dynamic adjustment costs, both linear as non-linear, are allowed to be correlated over time since material inputs are only relevant for current output. However, there cannot exist unobservables that directly affect material demand since they would make the inversion of the material demand function invalid.

${ }^{13} \beta_{t r}$ is defined as $\beta_{t r} \equiv \beta_{l} \phi_{T}$
} 
of the estimation strategy ${ }^{14}$. Here, the first stage only serves to seperate $\eta_{i t}$ from $\omega_{i t}$. Estimating the above equation gives a measure $\widehat{\Phi}_{i t}$ for the following term:

$$
\Phi_{i t}=\beta_{l} l_{i t}+\beta_{t r} \frac{L_{T, i t}}{L_{i t}}+\beta_{k} k_{i t}+\omega_{i t}
$$

which is in fact output net of the error term $\eta_{i t}$. The estimate $\widehat{\Phi}_{i t}$ will be used to identify the input coefficients in the second stage. Productivity $\omega_{i t}$ is assumed to follow a first-order Markov process and can be written as follows:

$$
\begin{aligned}
\omega_{i t} & =E\left[\omega_{i t} \mid I_{i t-1}\right]+\xi_{i t} \\
& =E\left[\omega_{i t} \mid \omega_{i t-1}\right]+\xi_{i t} \\
& =g\left(\omega_{i t-1}\right)+\xi_{i t}
\end{aligned}
$$

where $\xi_{i t}$ represents the innovation in productivity, namely the part of productivity in period $t$ that was unforeseen by the firm in period $t-1$. Given the timing assumption that the capital stock in period $t$ was decided in period $t-1$, this leads to a first moment condition which will allow us to identify the capital coefficient:

$$
E\left[\xi_{i t} \mid k_{i t}\right]=0
$$

Moreover, we assume that labor input and the amount of training do not depend on the innovation in productivity. For the labor coefficient, this is a more strict assumption than usually applied. However, in the Belgian context there are substantial labor adjustment costs such that labor is not freely variable input $^{15}$. Concerning the training variable, several human resources managers confirmed that the amount of training provided to workers is mostly decided one year in advance when making up the budget for the following year, which makes the amount of training independent from the innovation in productivity, $\xi_{i t}$. Consequently, the moment conditions to identify the labor and training coefficients in the second stage are:

\footnotetext{
${ }^{14}$ Ackerberg, Caves and Frazer (2006) argue there are serious identification issues with these methodologies due to collinearity between labor and the input demand function.

${ }^{15}$ For example, the OECD Employment Protection Legislation for Belgium is among the highest among the industrialized countries (higher scores indicate stricter regulation). Belgium has especially a high score for the notice and severence pay for individual dismissals, legislation concerning collective dismissals and temporary employment (OECD 2007).
} 


$$
E\left[\begin{array}{cc} 
& k_{i t} \\
\xi_{i t} \mid & l_{i t} \\
& L_{T, i t} / L_{i t}
\end{array}\right]=0
$$

In practice, we apply the first stage by non-parametrically regressing $y_{i t}$ on the production inputs. This gives us an estimate $\widehat{\Phi}_{i t}$ for $\Phi_{i t}=\beta_{l} l_{i t}+$ $\beta_{t r} \frac{L_{T, i t}}{L_{i t}}+\beta_{k} k_{i t}+\omega_{i t}$. Given a candidate value for the vector of input coefficients $\left(\beta_{l}, \beta_{k}, \beta_{t r}\right)$, we can compute $\widehat{\omega}_{i t}$ as follows:

$$
\widehat{\omega}_{i t}=\widehat{\Phi}_{i t}-\beta_{l} l_{i t}-\beta_{t r} \frac{L_{T, i t}}{L_{i t}}-\beta_{k} k_{i t}
$$

Next, we non-parametrically regress $\omega_{i t}$ on $\omega_{i t-1}$. The residuals from this regression $\widehat{\xi}_{i t}$ represent innovations in productivity, which are by assumption uncorrelated with training, labor and capital. This renders the above moment conditions and their sample analogue:

$$
\frac{1}{T} \frac{1}{N} \sum_{t} \sum_{t} \widehat{\xi}_{i t}\left(\begin{array}{c}
k_{i t} \\
l_{i t} \\
L_{T, i t} / L_{i t}
\end{array}\right)
$$

and we compute the sample analogue for each $\left(\beta_{l}, \beta_{k}, \beta_{t r}\right)$ For each new candidate value of $\left(\beta_{l}, \beta_{k}, \beta_{t r}\right)$, we obtain new estimates for $\xi_{i t}$ and we repeat this procedure until Equation (26) is minimized.

Given the input coefficients we found in the previous step, we find an estimate for total factor productivity by applying Equation (25). We use this estimate in the wage equation as control variable to pick up unobservables such as worker ability that influence wages of the workers. When not controlled for, these variables could cause our estimate for the wage premium to be biased ${ }^{16}$. Standard errors for all coefficients are obtained by using a bootstrap procedure with 500 replications. We apply a block bootstrap procedure such that the error term is allowed to be heteroskedastic and correlated over time $t$, for a given firm $i$ but is assumed to be independent over $i$.

\footnotetext{
${ }^{16}$ This is a similar strategy as applied in Frazer (2001).
} 


\section{Data Description}

Data is obtained from the Belfirst database. This database commercialized by Bureau Van Dijck includes information about all Belgian firms that need to file an annual report ${ }^{17}$ and is used by a number of other recent economic studies for example De Loecker (2006) and Abraham et al. (2009). Data are taken for the period 1997-2006 for both manufacturing and non-manufacturing firms. We select a number of key variables needed for the estimation of production functions such as value added, number of employees, material costs and the capital stock. For manufacturing sectors, these variables are deflated using price deflators at the 4 digit NACE level from the European Statistical Office ${ }^{18}$. For the services sectors we use a NACE 2 digit price deflator from the EU Klems database. In addition to the forementioned variables, Belgian firms are obliged to report information about formal training ${ }^{19}$ they provide to their employees. In particular, they have to report the number of employees that followed some kind of formal training as well as the hours spent on this training and the training costs. This allows us to obtain a firm-level measure of training for more than 170, 000 Belgian firms active in manufacturing and non-manufacturing sectors.

Table 1 provides some summary statistics of the dataset used. A Belgian firm active in the private sector employs on average 16.9 employees and generates a turnover of around 10 million euro. It pays an average wage of around 35, 000 euro and the average labor productivity (= value added per employee) equals 63, 900 euro. The second and third column compare these figures between firms that provided training to at least one employee in at least one year of the sample period with firms that have never trained an employee over the sample period. By comparing columns (2) and (3) it can be seen that less than $10 \%$ of the firms have ever invested in training of one of their employees. These firms are typically larger in terms of both employment and turnover. Moreover they pay higher wages and have a higher labor productivity. Surpirsingly, firms that provide training to their employees have a lower capital/labor ratio than non-training firms, but this result changes when we control for other characteristics as we will see below. In firms that train their workers in a given period, more than

\footnotetext{
${ }^{17}$ These are all Belgian enterprises with the exclusion of one-man businesses.

${ }^{18}$ For some 4 digit NACE sectors, price deflators are not reported. Here we use the 3 digit deflator.

${ }^{19}$ Formal training excludes training that takes place at the workfloor or self study. The training has to take place at a seperate training room or workfloor especially developed for training activities. Training can take place inside or outside the firm.
} 
$50 \%$ of the employees benefit from this training and spent on average almost 40 hours on this training. The average cost of training an employee equals more than 1,500 euro.

Table 2 shows the results of the regression of different key variables on a training dummy. This dummy equals 1 when a particular firm provides training to at least one of its employees in a given period and 0 otherwise. The dependent variable is expressed in logarithms, such that the coefficient on the training dummy can be interpreted as a percentage difference ${ }^{20}$. The first column of Table 2 shows the results of this exercise. A training firm is more than twice as large as a non-training firm and pays gross wages that are $36 \%$ higher. Labor productivity is also higher but the difference is smaller than for labor costs. In column (2), we control for the size of the firm, that is we include the number of employees as explanatory variable and in column (3), we also include NACE 4 digit dummies to control for sector characteristics. Now, labor productivity in training firms is $27 \%$ higher than in non-training firms while labor costs are only $18 \%$ higher. Note that when controlling for industry characteristics and the size of the firm, training firms have a higher capital-labor ratio than non-training firms.

There exists considerable variation in the amount of training across sectors. This is illustrated in Table 3 where the percentage of firms that provided training to their employees in 2006 is shown. We also show the percentage of workers that received some kind of (formal) training and the share of training costs in total labor costs. These two measures are weighted averages, that is the total share of trained workers in sector $j$ equals $\frac{\sum_{i} L_{T, i j}}{\sum_{i} L_{i j}}$, where $i$ is a firm indicator. Likewise, the share of training costs in total labor costs is the fraction of total training costs in sector $j$ divided by total labor costs in the sector. Despite that only slightly more than $5 \%$ of the firms provided training to at least one employee in 2006, more than $30 \%$ of all employees received training. This is because training firms are much larger than non-training firms as can be seen in Table 1 . Training costs make up almost $1 \%$ of total labor costs. In general manufacturing firms train more than their non-manufacturing counterparts. The most training intensive sectors include Manufacturing of Chemical Products, Telecommunications and Electricity Sector. Least training can be found in sectors such as Agriculture, Construction and Hotels \& Restaurants.

\footnotetext{
${ }^{20}$ Of course this is an approximation, certainly because for some variables, the difference between training and non-training firms is quite large.
} 


\section{Results}

\subsection{General Results}

Table 4 shows the results of estimating Equation (6) for all firms active in all sectors pooled together and for manufacturing firms and services seperately ${ }^{21}$. The first column for each subsample (Total, Manufacturing and Services) reports the estimation results for the full sample by applying ordinary least squares $(\mathrm{OLS} 1)^{22}$. Unfortunately, many firms do not report material $\operatorname{costs}^{23}$ such that the estimation methodology described in Section 3 can only be applied to a subset of of firms. To allow comparison between the ordinary least squares estimates and the estimates controlling for the endogeneity of inputs in the third column(ACF), we report in the second column results for least squares estimation (OLS2) on this subset of firms ${ }^{24}$. The estimates reported in column (1) show that training has a strongly significant and economically important effect on productivity. These coefficients imply that raising the share of trained workers by $10 \%$ points, will increase value added by $4.6 \%$. In column (2), OLS estimates for the subset of firms that report material costs are displayed. The coefficient on training drops somewhat to .300 but remains highly significant, both statistically as economically. A possible explanation for the coefficient to drop is that small firms are excluded from the sample. It is generally accepted that larger firms are more productive and as seen in Table 1, larger firms are more likely to train their employees. This positive correlation can bias upward the training coefficient in column (1). Controlling for the endogeneity of inputs (and training) causes the training coefficient to drop to .24 as shown in column (3). The estimates imply that value added increases by $2.4 \%$ in response to an increase of $10 \%$ points of the share of trained workers such that even after controlling for the possible endogeneity of training, there remains a substantially large impact of training on productivity. Note that the results mean that on average the marginal product of a trained worker is around $32 \%$

\footnotetext{
${ }^{21}$ Manufacturing firms are firms active in NACE sectors 15 to 36 . The other sectors are pooled together as "services" sectors.

${ }^{22}$ All regressions include year and industry dummies. Industry dummies are at the NACE 2 digit level for estimations on the whole sample and at the NACE 4 digit level for regressions at the sector level.

${ }^{23}$ Only large firms in Belgium have to submit a full version of the annual report. Smaller firms only have to submit a shorter version which does not include material costs. Firms are defined to be large if they have on average more than 50 employees, realize a turnover of more than 7.3 million euro or report a total value of assets of more than 3.65 million euro.

${ }^{24}$ All standard errors are robust to heteroskedasticity and within group correlation.
} 
$(=.243 / .764)$ higher than the marginal product of an untrained worker. The results for Manufacturing industries and Services seperately are comparable to each other, although we find a slightly stronger impact of training in services sectors.

In Table 5 results for the estimation of the wage equation (13) are reported. Again the exercise is done for the whole sample, the manufacturing sector and the services sector. For each different sample, three different specifications are estimated. First, log wage is regressed on the share of trained workers together with year and sector dummies (OLS1). Second, this exercise is repeated, but the sample is now restricted to firms included in the productivity estimation sample where we control for the endogeneity of inputs. As a result, the coefficient on training drops from .438 to .200 and a similar reasoning as with the productivity analysis can be applied. In the third specification, we add controls in the wage equation. In particular, we add the capital-labor ratio and total factor productivity as control variables. For total factor productivity, we use our estimate for $\omega_{i t}$ from the productivity equation and includes among others the ability of the labor force. By including total factor productivity in the wage equation we control for these factors that could be correlated with the amount of training in each firm. We find that in the total Belgian private sector, wages of trained employees are $16.7 \%$ higher than wages of untrained employees ${ }^{25}$.

Results in Table 4 and Table 5, show that the impact of training on wages is smaller than the impact on productivity ${ }^{26}$. The productivity premium for a trained worker is almost twice as high as his wage premium. We can statistically test the equality of $\phi_{T}$ and $\lambda_{T}$. Performing a Wald Test of this non-linear

\footnotetext{
${ }^{25}$ Note that the training variable measures the training flow, namely the number of workers trained in a given year. If the subsample of workers receives training is the same every period, this will lead the amount of training per trrained worker to be underestimated. If the workers that receive training are different every year, this will lead our estimate for the number of trained workers to be underestimated. We used the perpetual inventory method to construct a measure for the stock of trained workers and experimented with different depreciation rates, both dependent and independent of the number of workers that leave the firm. Our main results are robust to the use of the stock or flow of trained workers.

${ }^{26}$ We compare the first column of the wage equation with the first column of the production function, since in both specifications, we do not control for the possible endogeneity of training. Both coefficients will likely to be upward biased (for example more able workers are more likely to receive training and more able workers generate higher output and receive higher wages). The same reasoning explains why we compare the second and third specification of the wage equation with the second and third specification of the production function respectively. In the third specification, we control for the endogeneity of training in both the production function as in the wage equation.
} 
hypothesis (delta method) ${ }^{27}$ results in a Chi-square value of 128.2 which means that the null of equal coefficients can be rejected at any conventional significance level. The same is true for the manufacturing sector and services sector seperately with Chi-square values of 14.1 and 113.0 respectively. The fact that we find the impact of training on productivity to be higher than the impact on wages, gives support to the Acemoglu and Pischke (1999a) model that explains why firms invest in the general training of their employees. A necessary condition is that productivity of employees increases more than their wages in response to training ${ }^{28}$. An important consequence is that in contrast to Becker (1964), it is possible that there is underinvestment in training.

\subsection{Results Sector Heterogeneity}

So far, the assumption of equal production technologies in all Belgian sectors has been maintained. Clearly this assumption is too strong, especially when pooling manufacturing and services sectors together. In Tables 6 and 7 we estimate the impact of training on productivity for each NACE 2 digit sector seperately. The unweighted average for the training coefficient over all manufacturing sectors equals .231 when we estimate Equation (6) by ordinary least squares. Controlling for the possible endogeneity of training, we find that the average training coefficient drops to .177 . The labor coefficient decreases from .763 to .741 which indicates that our estimation procedure does a good deal in controlling for a likely upward bias on the labor and training coefficients. The results imply the marginal product of a trained worker is about $23 \%$ higher than that of an untrained worker. Focusing on the manufacturing industries, we find that for 14 out of 17 sectors, the training coefficient goes down compared to the least squares estimates. Largest productivity gains from training can be found in the Chemicals sector and Rubber and Plastic Sector ${ }^{29}$. Also the labor coefficient goes down in most sectors. Note that the sectors for which the labor coefficient increases, are sectors for which this coefficient is estimated relatively

\footnotetext{
${ }^{27}$ Again, to receive an estimate for $\phi_{T}$, we divide the coefficient on the share of trained workers reported in Table 4 , by the labor coefficient. Consequently, the null is: $\left(\beta_{t r} / \beta_{l}\right)-\lambda_{T}=$ 0 , where $\beta_{t r}=\phi_{T} \beta_{l}$. This hypothesis can be tested by applying the Delta method.

${ }^{28}$ Note that Becker (1964) also allows for the possibility that firms pays (part of) the training costs. For this to be the case, the training needs to be firm specific in nature. We will turn back to this issue in the next subsection.

${ }^{29}$ There are alse large gains in the sector of Wood Products, but here the training and labor coefficient are estimated imprecise.
} 
imprecise $^{30}$. The results for the services sectors are less satisfactory, which is not surprising given the problems with estimating production functions for services sectors. However, we do find positive and significant effects of training on worker productivity and for the majority of sectors, the training coefficient goes down when controlling for the possible endogeneity of inputs. The unweighted average of the training coefficient over all services sectors drops from 0.23 to 0.19 when moving from OLS to the adjusted Ackerberg et al. (2006) methodology. Again we find that productivity gains from training are slightly larger in the services sectors compared to manufacturing sectors.

In Tables 8 and 9, we report results from estimating the wage equation for each NACE 2 digit sector seperately. In both tables, we only report the coefficient on the share of trained workers for expositional reasons. Again, the forementioned three specifications are reported. The number of observations refers to those used in the first specification, the number of observations used in the second and third specification are the same as in the productivity tables. Similar to the resuls of all sectors pooled together, the training coefficient drops when moving from the full sample to the restricted sample (with only firms that report material costs). Also inserting control variables in the wage equation lowers the training coefficient. The unweighted average of the training coefficient in this specification equals 0.122 , which means that on average a trained employee earns $12 \%$ more than its untrained counterpart. For the manufacturing and services sectors seperate, this average equals .142 and .100 respectively.

Comparing the impact of job related training with the impact of general education on wages, one finds these similar in magnitude. In his survey, Card (1999) reports estimates for the impact of one year of education on wages between 5 and $15 \%$ while we estimate the wage premium for trained employees to be $12 \%$. However, note that the average training duration is only around 2 weeks, implying much larger returns to a week of training compared to a week of schooling. A possible explanation could be that work related training is much more designed to increase productivity directly than general education. While large parts of the general education system are devoted to increasing general knowledge not directly applicable in a professional carreer, one would not expect this to be the case for firm induced training. Note that our estimates for

\footnotetext{
${ }^{30}$ For example the standard error for the sectors Wearing Apparel, Wood Products and Rubber and Plastic are considerably higher than those of other sectors.
} 
the impact of training on productivity and wages are considerably smaller that those obtained by Dearden et al. (2006) for UK manufacturing firms ${ }^{31}$. They observe training at the sectoral level instead of at the firm level and so their measure includes possible spillovers of training from workers who switch from one employer to another ${ }^{32}$.

Figure 1 combines the estimates of the impact on training and productivity. The $45^{\circ}$ line is plotted, such that all observations above this line represent sectors for which the impact of training on productivity is larger than the impact of training on wages ${ }^{33}$. Most of the sectors are located above this line which is consistent with Acemoglu and Pischke ${ }^{34}$ (1999a). The correlation between the two measures equals .64 and is highly significant.

\subsection{Training as a continuous variable}

In Table 10 we redefine the training variable as average training costs per employee and estimate Equations (10) and (15) to determine the impact of training intensity on productivity and wages respectively. Again results are reported for the whole sample and manufacturing and services seperate. we control for the possible endogeneity of training and add controls in the wage equation. The coefficient on average training intensity in the production function equals .107 implying that $\beta_{T}$ equals .139 which is considerably higher than our estimate for the impact of training intensity on wages (.090). These figures imply that increasing the average training costs per employee with $€ 100$, raises output by $1 \%$. The difference between the wage and productivity premium is again highly significant. Also for the manufacturing and services sectors seperately, the productivity premium is higher than the wage premium, although the difference is not statistically significant for the manufacturing industries. A summary of the results for sector specific estimates are reported in the last columns and Figure

\footnotetext{
${ }^{31}$ They find that raising the fraction of trained workers with $10 \%$, increases value added by $6 \%$ and wages by $3 \%$.

${ }^{32}$ However, this can only explain part of the difference since their estimate is almost three times as large as ours.

${ }^{33}$ We left out sectors 1-Agriculture, 64-Post and Telecommunications and 65-Financial Intermediation which reported all three a very large impact on productivity and a low or even zero impact on wages. Moreover, the number of observations used in the estimation was limited for these sectors.

${ }^{34}$ This finding on itself is also consistent with firm specific training and perfect competition in the labor market. An issue we will turn back to in the next section.
} 
2 where the $45^{\circ}$ line is added ${ }^{35}$. It can be seen that for the majority of sectors, investing in training has a larger impact on marginal productivity of a worker than on its wage. The correlation between the impact on productivity and on wages equals .76 and is highly significant.

\subsection{Other Types of Specification}

We performed a number of robustness checks to show that results are not driven by one particular specification. First, we dropped the linear approximation of the training term in Equations 2 and 13. In the estimation strategy for the production function, we adjust the computation of the productivity estimates $\widehat{\omega}_{i t}=\widehat{\Phi}_{i t}-\beta_{l} l_{i t}-\beta_{l} \ln \left(1+\phi_{T, i t} \frac{L_{T, i t}}{L_{i t}}\right)-\beta_{k} k_{i t}$ and instead of applying linear techniques to estimate the wage equation we use non-linear least squares. A summary of the results is reported in Table 11. Results are qualitatively and quantitively similar to the linear approximation ${ }^{36}$, although the magnitude of the training effect is estimated to be slightly higher. Again, the productivity premium exceeds the wage premium. Furthermore, we estimate Equations (2) and (13) with Zellner's seemingly unrelated regression (SUR) estimator, which allows the error terms of both equations to be correlated. Again the main results hold. in that the productivity premium is higher than the wage premium for trained employees ${ }^{37}$. The difference is also statistically significant. Third, we add the average salary in a firm as control variable in the production function instead of applying the Ackerberg, Caves and Frazer (2006) estimation strategy. The average firm-level wage should pick up unobserved labor quality and productivity differences if workers are paid their marginal product. Also this strategy leaves our main conclusions unaffected.

\subsection{Worker heterogeneity}

In this subsection, we include other forms of worker heterogeneity in the empirical framework. First we infer whether there exist differences in the impact of training between male and female workers. Second, we include measures to

\footnotetext{
${ }^{35}$ Sectors 14-Other Mining and Quarrying, 21-Pulp and Paper Products, 37-Recycling and 64-Post and Telecommunications are left out.

${ }^{36}$ Note that the reported coefficients are direct estimates for $\phi_{T}$ and should be compared with $\beta_{t r} / \beta_{l}$ in Table 4.

${ }^{37}$ Here we do not control for the possible endogeneity of training in the production function. For the wage equation, we exclude the control variables. One can argue that the bias of the estimated training coefficient is more or less the same in both the wage equation and production function .
} 
make a distinction between low and high skilled workers. The empirical framework to estimate the productivity and wage premia when the workforce can be divided among several dimensions is outlined in Appendix A.

\section{Gender Differences in Training}

In Table 12 we report results for the estimation of Equations (A.4) and (A.10) where we divide the labor force into trained males, untrained males, trained females and untrained females to infer whether there is a differential impact of training on wages and productivity of males and females. For brevity, we only report results for the specification where we control for the endogeneity of training in both the production function and wage equation. For the production function, we report direct estimates for $\phi_{T}, \phi_{F}$ and $\phi_{F T}$ that measure productivity premia for the different worker characteristics. The impact of training on productivity $\phi_{T}$ equals .328 and is comparable in magnitude with estimates from previous specifications. Again, the productivity differential between trained and untrained workers is higher in the services sector than in the manufacturing sector. The wage premium for trained workers is $14.7 \%$ and is again estimated to be smaller than the productivity premium. We find that productivity of female workers is not significantly different from productivity of male workers. However, earnings of female workers are around $16 \%$ lower in the Belgian private sector which is consistent with previous studies that have shown female workers earn lower wages than their male counterparts (e.g. Hellerstein and Neumark, 1999). Surprisingly, while there exists no difference in productivity premium of training between male and female workers $\left(\phi_{F T}\right)$, the difference in wages between males and females seems to disappear for employees that reveived work related training. The interaction between female and training $\lambda_{F T}$ is positive and significant, which means that wages of female workers increase more in respons to training than wages of male workers. This result can be compared with Booth (1991) who finds that in the UK wages of male employees increase by $10 \%$ while female earnings rise with $16 \%$ in response to training.

\section{Other Types of Worker Heterogeneity}

There could be concerns that our methodology does not fully control for worker heterogeneity. To address these concerns, we include two typers of worker heterogeneity in our production function and wage equation estimates. First, we 
make a distinction between blue collar workers, white collar workers and managers. Second, we construct a measure for the education level of the worker and finally we include firm fixed effects.

Besides the number of trained employees at each firm, we also observe the number of blue collar workers, the number of white collar workers and the number of managers active in a firm. Inserting these types of worker heterogeneity ${ }^{38}$ and applying again the Ackerberg, Caves and Frazer (2006) methodology leads to conclusions comparable to those in our base specification. Results for sectors pooled together are reported in Table 13. The coefficient on training drops slightly to .18 in the production function and to .09 in the wage equation. The median of the training coefficient in the production function is .14 and .11 in the wage equation when estimating the model for each NACE 2 digit sector seperately.

Moreover, we construct a measure for the average education level of the workers. Although we do not posess detailed information about the skill composition of workers, we observe the education level of every employee that leaves or enters the firm in a given year ${ }^{39}$. We only observe this information for a limited sample of large firms ${ }^{40}$. Using this data, we compute the educational level of the inflow and outflow of employees and we take the average over all years to retrieve a proxy for the educational composition of each firm's workforce. We include the share of high-educated employees in both the production function and wage equation and estimate both equations controlling for the possible endogeneity of inputs (cf. Equations (A.8) and (A.14). As can be seen from the last two rows of Table 13, the training coefficient drops somewhat compared to the base specification. However, the impact of training on productivity remains larger than the impact on wages. The results also indicate ${ }^{41}$ that a schooled worker is almost two times as productive as an unschooled worker and earns a substantially higher wage but this wage premium is lower than the productivity

\footnotetext{
${ }^{38}$ For the whole sample, around $52 \%$ of the workforce is blue-collar, $44 \%$ white collar and $1.4 \%$ management. In the manufacturing sector the shares are respectively $66 \%, 31 \%$ and $1.6 \%$ and in the services sectors respectively $45 \%, 51 \%$ and $1.3 \%$. The percentages do not sum up to $100 \%$ because some of the workers have an undefined contract and can not be classified.

${ }^{39}$ More precise we observe whether the highest education of an entrant or departure is primary, secundary, higher or university. We define an employee to be high-educated if he received higher or university education and low-educated if he received at most primary or secundary education.

${ }^{40}$ These are firms that have at least 50 employees, realize a turnover of more than $€ 7.3$ million or have a total book value of their assets that exceeds $€ 3.65$ million.

${ }^{41}$ These figures are not reported in the table for expositional reasons.
} 
premium, namely $70 \%$.

Finally we repeated the exercise with firm fixed effects. These should pick up all unobserved worker heterogeneity that is constant over time. Unfortunately, using fixed effects to estimate production functions does not perform very well. When there is measurement error in the input variables, first or mean differencing can exacerbate the bias in the input coefficients estimates. This is especially true for highly persistent input variables (Griliches and Hausman 1986) such as capital and training. Results are reported in Appendix B. Table B.1 shows that for the production function, as expected, unreasonably low estimates of returns to scale are obtained due to a large decrease in both the capital and labor coefficient. Also the training coefficient drops substantially. However, comparing the impact of training on productivity and wages, we still find the productivity premium for trained employees to be substantially higher than the wage premium $^{42}$ and the difference is statistically significant. Estimating training impact by sector shows that again for the majority of sectors the productivity premium of trained workers is higher than the wage premium of trained workers as shown if Figure B.1. The average productivity premium across all sectors equals .10 while the average wage premium is not higher than .026. Again, we suspect these coefficients to be severely downward biased in contrast to the coefficients obtained by applying the Ackerberg, Caves and Frazer (2006) methodology.

\subsection{Firm specific versus general training}

Note that the gap between the productivity and wage premium for trained employees can be explained equally well by perfect competition and firm specific training as by imperfect competion and general training. Which of the two theories is the best explanation for our results? Recall that under firm specific training the acquired skills are not applicable in other firms and the firm could pay for all training costs. The firm recoups all the benefits after training through the higher marginal product of trained workers and equal wages of trained and untrained workers. Becker (1964) noted that it could be optimal for both workers and firms to share benefits of training, namely under the form of higher wages but still lower than the marginal product. Consequently, firms are less likely to fire trained workers. Moreover, trained workers are less likely to quit the firm

\footnotetext{
${ }^{42}$ Although we suspect these estimates to be downward biased, the bias in the production function should be as large as the bias in the wage equation and thus it still makes sense to compare both estimates.
} 
since skills are firm specific and they will earn lower wages at other employers. In general one would expect both dismissal and quit rates to be lower in firms that provide a substantial amount of training.

Under imperfect competition in the labor market and general training, a negative correlation between the dismissal rate and training would arise since the difference between wage and marginal product is higher for trained workers. However, when for example the presence of unions is the main source of wage compression, it is possible that training has no impact on quit rates of workers since trained workers could earn the same wage at other firms. To summarize, we would expect a negative impact of training on the dismissal rate with perfect competition and specific training as well as with imperfect competition and general training. However, with perfect competition and specific training worker quit rates should be influenced by training while this is not necessarily the case with general training and imperfect competition.

Our dataset allows us not only to compute general seperation rates, but also to distinguish between whether these seperations are dismissals initiated by the firm or quits initiated by the worker ${ }^{43}$. When we regress the quit and dismissal rates on the share of trained workers lagged one and two periods, we find that dismissal rates are negatively and significantly affected by the lagged share of trained employees ${ }^{44}$ as can be seen from Table C.1. Quit rates however seem to be unaffected by the number of trained workers. The coefficient on the lagged share of trained employees is not significantly different from zero ${ }^{45}$. The share of trained employees lagged two periods has even a positive and significant impact on the quit rates ${ }^{46}$. Although not a formal proof, these results suggest that the training is most likely to be general in nature instead of firm specific. Moreover, recall that we observe formal training, which is more likely to be general in nature.

\section{Conclusions}

This paper empirically investigates the impact of firm provided training on both wages and productivity. To this end we make use of a firm level data set of more

\footnotetext{
${ }^{43}$ We only observe these variables for the subset of large firms.

${ }^{44}$ We control not only for firm fixed effects but include also inflows of employees both contemporaneous and lagged one period and year dummies to control for business cycles.

${ }^{45}$ The $p$-value is equal to .333 .

${ }^{46}$ When aggregating training and seperation rates at the 4 digit level, there was a substantial and significant correlation between the dismissal rate and share of trained employees but not between the quit rate and share of trained employees.
} 
than 170,00 firms active in Belgium. We are able to measure for each firm the amount of employees that received some kind of formal training as well as the training costs and the hours spent on training for the period 1997 to 2006. After controlling for the possible endogeneity of training we find that training boosts marginal productivity of an employee more than it increases its wage. More precise, our results indicate that the productivity premium for a trained employee is on average around $23 \%$ while the wage premium is only $12 \%$. We find a slightly higher impact of training in services compared to manufacturing sectors. Our results are robust accross different specifications and definitions of the training variable. Also controlling for different kinds of worker heterogeneity leaves our main findings unaffacted. There exists considerable heterogeneity in the impact of training on both productivity and wages. Sectors with the largest effects of training include the Chemical sector and Rubber and Plastic sector.

The results are consistent with recent theories such as Acemoglu and Pischke (1999a) that explain firm provided general training by imperfect competition in the labor market and wage compression. This finding can have important policy implications. The standard result of Becker (1964) is that if workers are not credit constrained, training investments are efficient and as such, government intervention is unnecessary or should be directed to the credit markets. However, with imperfect labor markets and a compressed wage structure, there could be underinvestment in training from a social point of view. For example, when making their training decisions, firms do not take into account the possible externalities for future employers of trained workers (Acemoglu and Pischke 1999b). This opens possibilities for the government to implement training subsidies. 


\section{References}

Abraham F., J. Konings and S. Vanormelingen (2009). "The effect of globalization on union bargaining and price-cost margins of firms", Review of World Economics, forthcoming.

Acemoglu, D. and J.S. Pischke (1999a). "The Structure of Wages and Investment in General Training." Journal of Political Economy 107(3): 539-572.

Acemoglu, D. and J.S. Pischke (1999b). "Beyond Becker: Training in Imperfect Labour Markets." The Economic Journal 109(Feb.): 112-142.

Ackerberg, D., Benkard, L., Berry, S., and Pakes, A. (2005) "Econometric Tools for Analyzing Market Outcomes", Forthcoming chapter in Handbook of Econometrics, Volume 6

Ackerberg D., K. Caves and G. Frazer (2006). "Structural Identification of Production Functions", mimeo.

Bartel, A. P. (1995). "Training, Wage Growth, and Job Performance: Evidence from a Company Database." Journal of Labor Economics 13(3): 401-425.

Becker, G.S. (1964). Human Capital. Chicago: The University of Chicago Press.

Black, S. E. and L. M. Lynch (1996). "Human-Capital Investments and Productivity." The American Economic Review 86(2): 263-267.

Black, S. E. and L. M. Lynch (2001). "How To Compete: The Impact Of Workplace Practices And Information Technology On Productivity." The Review of Economics and Statistics 83(3): 434-445.

Blundell, R. and S. Bond (1998). "Initial conditions and moment restrictions in dynamic panel data models." Journal of Econometrics 87(1): 115-143.

Bond, S. and M. W. Söderbom (2005). Adjustment costs and the identification of Cobb Douglas production functions, Institute for Fiscal Studies.

Booth, A. L. (1991). "Job-Related Training: Who Receives it and What Is it Worth? ." Oxford Bulletin of Economics \& Statistics 53(3): 281-294.

Card, D. (1999). The causal effect of education on earnings. Handbook of Labor Economics. O. Ashenfelter and D. Card, Elsevier. Volume 3, Part 1: 1801-1863.

Dearden, L., Reed, H., \& Reenen, J. V. (2006). "The Impact of Training on Productivity and Wages: Evidence from British Panel Data." Oxford Bulletin of Economics and Statistics 68(4): 397-421.

De Loecker, J. (2006). "Product Differentiation, Multi-product Firms and Estimating the Impact of Trade Liberalization on Productivity." National Bureau of Economic Research Working Paper Series No. 13155. 
European Commission (2007) "Strengthening Continuing Vocational Training at the Initiative of the Enterprise." Employment in Europe 2007, Office for official publications of the European Communities, Luxembourg.

Frazer G. (2001) "Linking Firms and Workers: Heterogeneous Labor and Returns to Education." mimeo Yale University

Griliches and Hausman (1986) "Errors in Variables in Panel Data", Journal of Econometrics, 31(1), pp. 93-118.

Hellerstein, J. K. and D. Neumark (1999). "Sex, wages, and productivity: An empirical analysis of Israeli firm-level data." International Economic Review 40(1): 95 .

Hellerstein, J. K., D. Neumark, and K. R. Troske. (1999). "Wages, Productivity, and Worker Characteristics: Evidence from Plant Level Production Functions and Wage Equations." Journal of Labor Economics 17(3): 409-446.

Holzer, H. J., R. N. Block, M. Cheatham, and J.H. Knott (1993). "Are training subsidies for firms effective? The Michigan experience." Industrial \& Labor Relations Review 46(4): 625-636.

Jones, P. (2001). "Are educated workers really more productive?" Journal of Development Economics 64(1): 57-79.

Lucas, R. E. (1988). "On the mechanics of economic development." Journal of Monetary Economics 22(1): 3-42.

Levinsohn, J. and A. Petrin (2003). "Estimating Production Functions Using Inputs to Control for Unobservables." Review of Economic Studies 70(243): $317-341$.

Mincer, J., (1974). Schooling, Experience, and Earnings, Colombia Univ. Press, New York

Moretti, E. (2004). "Workers' Education, Spillovers, and Productivity: Evidence from Plant-Level Production Functions." American Economic Review 94(3): 656-690

Olley, G. S. and A. Pakes (1996). "The Dynamics of Productivity in the Telecommunications Equipment Industry." Econometrica 64(6): 1263-1297.

OECD (2007). "OECD Economic Surveys: Belgium", Paris.

Van Biesebroeck, J. (2007). "Wages Equal Productivity. Fact or Fiction?". Working Paper University of Toronto, Department of Economics. 


\section{Tables}

Table 1: Summary Statistics

\begin{tabular}{lrrr}
\hline \hline & Total & Training & No Training \\
\hline Employment & 16.9 & 84.8 & 6.67 \\
Turnover $(\times 1000 €)$ & 10,078 & 37,245 & 2,820 \\
Labor Cost per Worker $(\times 1000 €)$ & 35.1 & 44.8 & 33.7 \\
Labor Productivity $(\times 1000 €)$ & 63.9 & 73.0 & 62.5 \\
Capital/Labor $(\times 1000 €)$ & 75.5 & 69.8 & 76.3 \\
Observations & 919,077 & 54,867 & 864,210 \\
Nr. Firms & 171,210 & 15,499 & 155,711 \\
\hline Proportion of Trained Workers & & 0.53 & \\
Cost of Training per Worker Trained & & 3,581 & \\
Hours Training per Worker Trained & & 39.8 & \\
\hline \hline
\end{tabular}

Table 2: Summary Regressions

\begin{tabular}{lcccc}
\hline \hline Dependent Var. & $(1)$ & $(2)$ & $(3)$ & \# Obs \\
\hline Employment (ln) & $2.27^{*}$ & & $1.97^{*}$ & 919,077 \\
Turnover (ln) & $2.56^{*}$ & $0.31^{*}$ & $0.26^{*}$ & 380,091 \\
Lab. Costs (ln) & $0.36^{*}$ & $0.27^{*}$ & $0.18^{*}$ & 919,077 \\
Lab. Prod. (ln) & $0.24^{*}$ & $0.40^{*}$ & $0.27^{*}$ & 910,615 \\
Capital/Labor (ln) & $-0.27^{*}$ & $0.35^{*}$ & $0.27^{*}$ & 891,984 \\
\hline \hline
\end{tabular}
* Denotes siginificant at 1 perc. level.
(1) Regression of dependent variable on training dummy,
(2) Similar to (1) but controlling for size (employment),
(3) Similar to (2) but with NACE 4 digit dummies. 


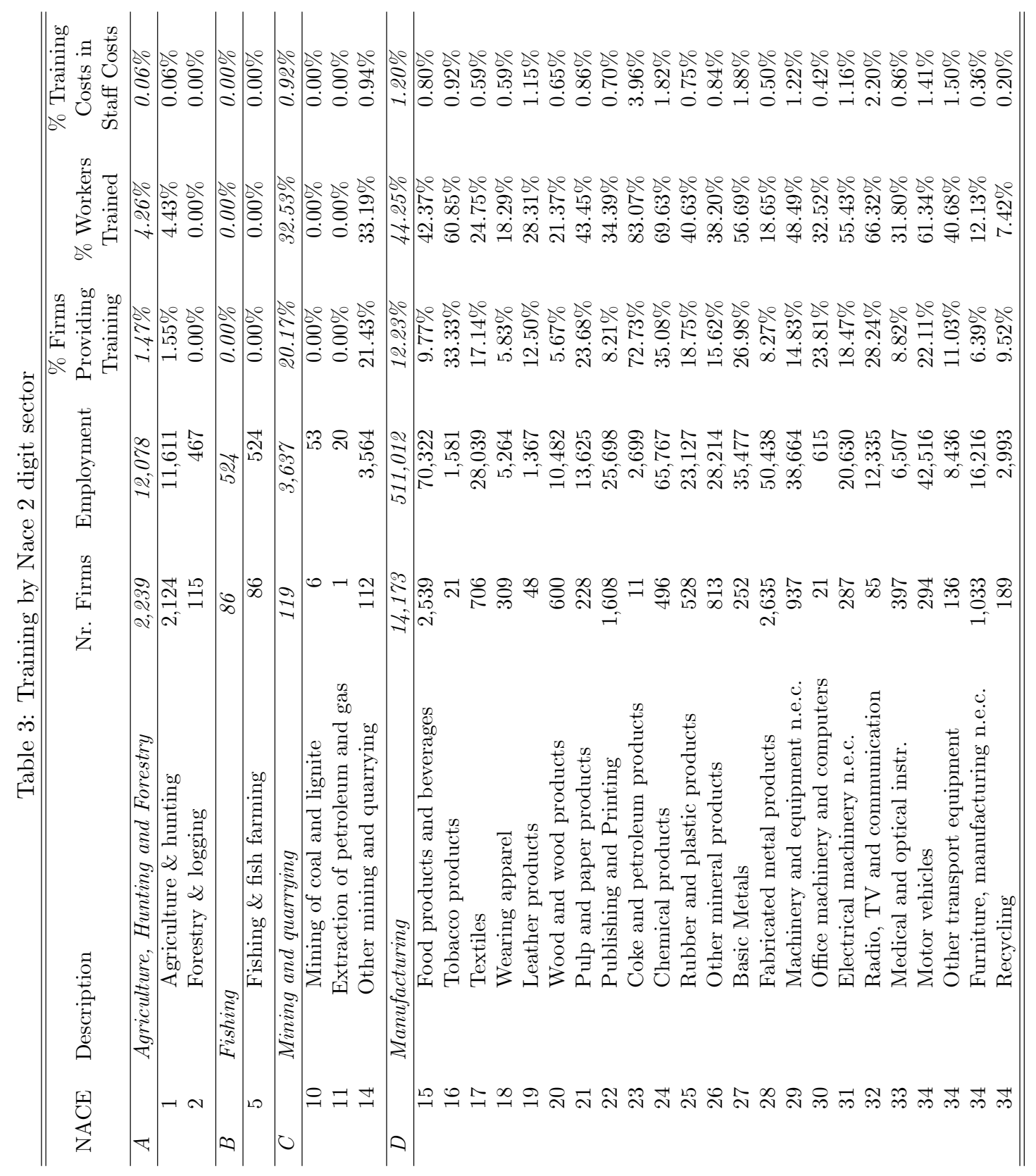




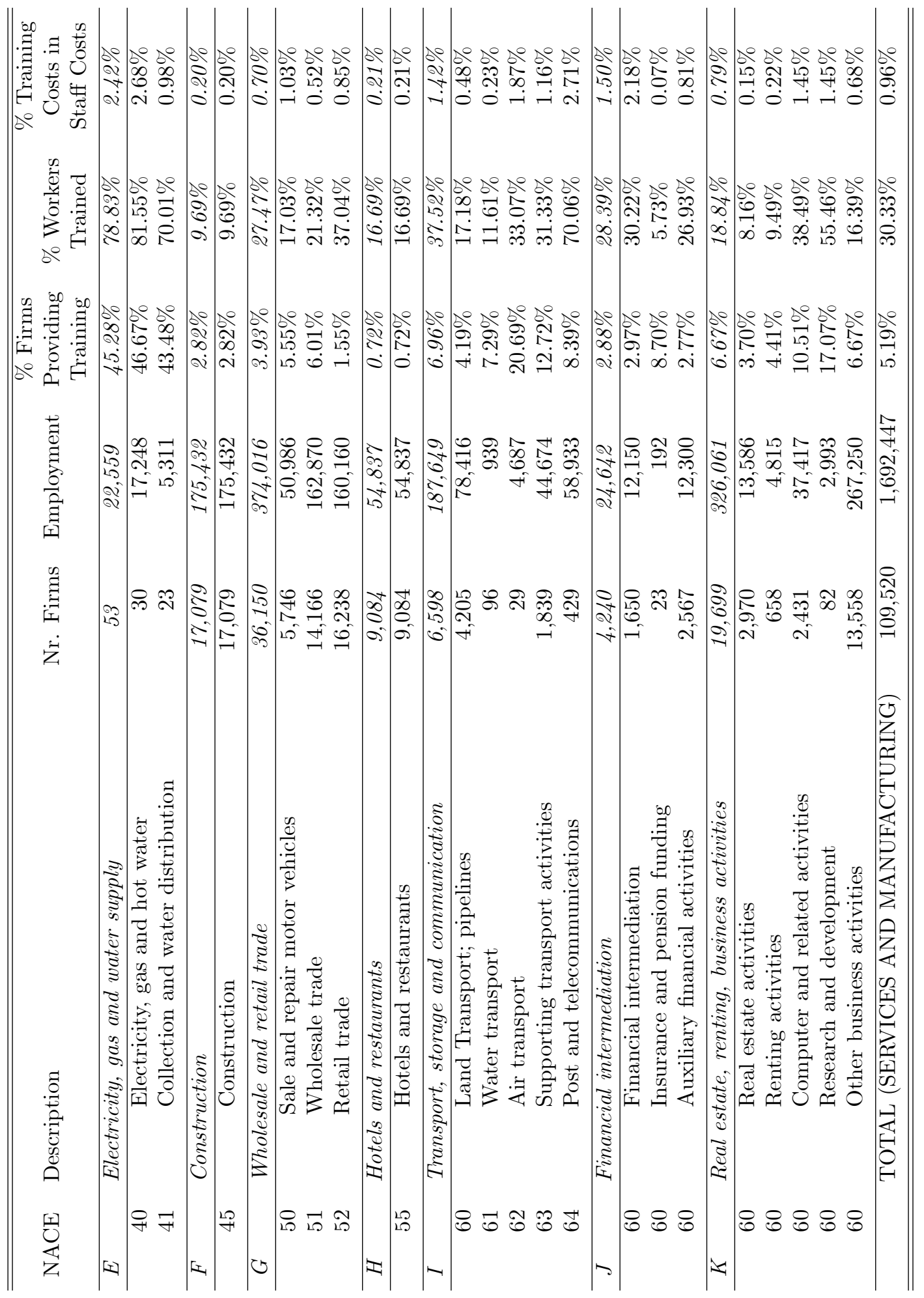


Table 4: Impact of Training on Productivity

\begin{tabular}{cccccccccc}
\hline \hline & \multicolumn{3}{c}{ Total } & \multicolumn{4}{c}{ Manufacturing } & \multicolumn{3}{c}{ Services } \\
& OLS1 & OLS2 & ACF & OLS1 & OLS2 & ACF & OLS1 & OLS2 & ACF \\
\hline Labor & .785 & .747 & .764 & .802 & .767 & .791 & .780 & .735 & .751 \\
& $(.001)$ & $(.004)$ & $(.008)$ & $(.003)$ & $(.007)$ & $(.015)$ & $(.001)$ & $(.005)$ & $(.009)$ \\
Capital & .165 & .123 & .088 & .178 & .151 & .129 & .163 & .115 & .081 \\
& $(.001)$ & $(.002)$ & $(.004)$ & $(.002)$ & $(.005)$ & $(.008)$ & $(.001)$ & $(.003)$ & $(.004)$ \\
Training & .460 & .315 & .243 & .403 & .300 & .215 & .461 & .301 & .257 \\
& $(.008)$ & $(.010)$ & $(.010)$ & $(.015)$ & $(.016)$ & $(.017)$ & $(.008)$ & $(.012)$ & $(.014)$ \\
& & & & & & & & & \\
\hline Obs & 804,293 & 73,930 & 73,930 & 123,834 & 23,345 & 23,345 & 677,764 & 50,585 & 50,585 \\
Clust & 135,865 & 13,757 & 13,757 & 18,422 & 3,878 & 3,878 & 117,021 & 9,879 & 9,879 \\
\hline \hline
\end{tabular}

Standard errors are computed using a block bootstrap procedure with 500 replications and are robust against

heteroskedasticity and intra-group correlation

Table 5: Impact of Training on Wages

\begin{tabular}{|c|c|c|c|c|c|c|c|c|c|}
\hline & \multicolumn{3}{|c|}{ Total } & \multicolumn{3}{|c|}{ Manufacturing } & \multicolumn{3}{|c|}{ Services } \\
\hline & OLS1 & OLS2 & OLS3 & OLS1 & OLS2 & OLS3 & OLS1 & OLS2 & OLS3 \\
\hline Training & $\begin{array}{l}.438^{*} \\
(.006)\end{array}$ & $\begin{array}{l}.200^{*} \\
(.006)\end{array}$ & $\begin{array}{l}.167 \\
(.007)\end{array}$ & $\begin{array}{l}.432^{*} \\
(.009)\end{array}$ & $\begin{array}{l}.219^{*} \\
(.009)\end{array}$ & $\begin{array}{l}.187^{*} \\
(.011)\end{array}$ & $\begin{array}{l}.440^{*} \\
(.007)\end{array}$ & $\begin{array}{l}.190^{*} \\
(.009)\end{array}$ & $\begin{array}{l}.165^{*} \\
(.009)\end{array}$ \\
\hline $\ln (\mathrm{K} / \mathrm{L})$ & & & $\begin{array}{c}-.015^{*} \\
(.002)\end{array}$ & & & $\begin{array}{l}.017^{*} \\
(.004)\end{array}$ & & & $\begin{array}{l}-.022^{*} \\
(.002)\end{array}$ \\
\hline TFP & & & $\begin{array}{l}.337^{*} \\
(.006)\end{array}$ & & & $\begin{array}{l}.306^{*} \\
(.008)\end{array}$ & & & $\begin{array}{l}.343^{*} \\
(.007)\end{array}$ \\
\hline Obs. & 828,303 & 73,816 & 73,816 & 126581 & 23,318 & 23,318 & 701,722 & 50,498 & 50,498 \\
\hline Nr. Clusters & 139,133 & 13,746 & 13,746 & 18759 & 3,878 & 3,878 & 120,374 & 9,868 & 9,868 \\
\hline R Squared & .134 & .184 & .321 & .154 & .221 & .336 & .132 & .167 & .309 \\
\hline$C h i^{2} \phi_{T}=\lambda_{T}$ & & 333.6 & 128.2 & & 89.4 & 14.1 & & 231.6 & 113.0 \\
\hline
\end{tabular}

Standard errors are computed using a block bootstrap procedure with 500 replications and are robust against heteroskedasticity and intra-group correlation

* denotes significance at $1 \%$ level 
Table 6: Results Productivity Manufacturing Sectors

\begin{tabular}{|c|c|c|c|c|c|c|c|c|}
\hline & & & & & & ing & Nr. & bs \\
\hline & OLS & $\mathrm{ACF}$ & OLS & $\mathrm{ACF}$ & OLS & $\mathrm{ACF}$ & Obs & Clust \\
\hline 15 Food Products & $\begin{array}{l}.789 \\
(.018)\end{array}$ & $\begin{array}{c}.729 \\
(.035)\end{array}$ & $\begin{array}{l}.175 \\
(.016)\end{array}$ & $\begin{array}{c}.174 \\
(.036)\end{array}$ & $\begin{array}{l}.165 \\
(.031)\end{array}$ & $\begin{array}{l}.130 \\
(.034)\end{array}$ & 3,571 & 600 \\
\hline 17 Textile Products & $\begin{array}{l}.753 \\
(.027)\end{array}$ & $\begin{array}{c}.720 \\
(.094)\end{array}$ & $\begin{array}{l}.154 \\
(.018)\end{array}$ & $\begin{array}{l}.133 \\
(.038)\end{array}$ & $\begin{array}{l}.319 \\
(.042)\end{array}$ & $\begin{array}{l}.227 \\
(.047)\end{array}$ & 1,729 & 298 \\
\hline 18 Wearing Apparel & $\begin{array}{c}.665 \\
(.112)\end{array}$ & $\begin{array}{c}.675 \\
(.240)\end{array}$ & $\begin{array}{c}.227 \\
(.040)\end{array}$ & $\begin{array}{l}.160 \\
(.094)\end{array}$ & $\begin{array}{l}.101 \\
(.193)\end{array}$ & $\begin{array}{c}.049 \\
(.124)\end{array}$ & 364 & 66 \\
\hline 20 Wood Products & $\begin{array}{c}.668 \\
(.038)\end{array}$ & $\begin{array}{c}.700 \\
(.266)\end{array}$ & $\begin{array}{l}.142 \\
(.034)\end{array}$ & $\begin{array}{l}.102 \\
(.074)\end{array}$ & $\begin{array}{c}.659 \\
(.135)\end{array}$ & $\begin{array}{l}.264 \\
(.106)\end{array}$ & 588 & 110 \\
\hline 21 Paper Products & $\begin{array}{c}.853 \\
(.060)\end{array}$ & $\begin{array}{c}.658 \\
(.179)\end{array}$ & $\begin{array}{l}.120 \\
(.035)\end{array}$ & $\begin{array}{c}.269 \\
(.099)\end{array}$ & $\begin{array}{l}.149 \\
(.070)\end{array}$ & $\begin{array}{l}.036 \\
(.057)\end{array}$ & 685 & 98 \\
\hline 22 Publishing & $\begin{array}{c}.804 \\
(.027)\end{array}$ & $\begin{array}{c}.828 \\
(.071)\end{array}$ & $\begin{array}{l}.103 \\
(.017)\end{array}$ & $\begin{array}{c}.077 \\
(.023)\end{array}$ & $\begin{array}{l}.154 \\
(.064)\end{array}$ & $\begin{array}{l}.157 \\
(.049)\end{array}$ & 1,764 & 319 \\
\hline 24 Chemical Products & $\begin{array}{c}.841 \\
(.029)\end{array}$ & $\begin{array}{c}.816 \\
(.067)\end{array}$ & $\begin{array}{l}.125 \\
(.026)\end{array}$ & $\begin{array}{l}.116 \\
(.047)\end{array}$ & $\begin{array}{l}.405 \\
(.063)\end{array}$ & $\begin{array}{c}.305 \\
(.053)\end{array}$ & 2,134 & 331 \\
\hline 25 Rubber and Plastic & $\begin{array}{c}.788 \\
(.030)\end{array}$ & $\begin{array}{c}.803 \\
(.228)\end{array}$ & $\begin{array}{l}.183 \\
(.022)\end{array}$ & $\begin{array}{l}.172 \\
(.064)\end{array}$ & $\begin{array}{l}.341 \\
(.047)\end{array}$ & $\begin{array}{l}.255 \\
(.050)\end{array}$ & 1,477 & 227 \\
\hline 26 Mineral Products & $\begin{array}{c}.798 \\
(.023)\end{array}$ & $\begin{array}{c}.773 \\
(.065)\end{array}$ & $\begin{array}{l}.135 \\
(.020)\end{array}$ & $\begin{array}{l}.157 \\
(.047)\end{array}$ & $\begin{array}{c}.219 \\
(.048)\end{array}$ & $\begin{array}{l}.174 \\
(.043)\end{array}$ & 1,917 & 311 \\
\hline 27 Basic Metals & $\begin{array}{c}.802 \\
(.034)\end{array}$ & $\begin{array}{c}.772 \\
(.112)\end{array}$ & $\begin{array}{l}.171 \\
(.025)\end{array}$ & $\begin{array}{l}.191 \\
(.049)\end{array}$ & $\begin{array}{l}.105 \\
(.068)\end{array}$ & $\begin{array}{c}.084 \\
(.060)\end{array}$ & 995 & 146 \\
\hline 28 Metal Products & $\begin{array}{c}.760 \\
(.020)\end{array}$ & $\begin{array}{c}.733 \\
(.033)\end{array}$ & $\begin{array}{l}.139 \\
(.012)\end{array}$ & $\begin{array}{c}.129 \\
(.016)\end{array}$ & $\begin{array}{l}.176 \\
(.038)\end{array}$ & $\begin{array}{l}.102 \\
(.039)\end{array}$ & 2,779 & 478 \\
\hline 29 Machinery & $\begin{array}{c}.822 \\
(.034)\end{array}$ & $\begin{array}{c}.789 \\
(.076)\end{array}$ & $\begin{array}{l}.114 \\
(.021)\end{array}$ & $\begin{array}{l}.134 \\
(.029)\end{array}$ & $\begin{array}{l}.287 \\
(.051)\end{array}$ & $\begin{array}{l}.197 \\
(.051)\end{array}$ & 1,681 & 283 \\
\hline 31 Electrical Machinery & $\begin{array}{c}.800 \\
(.038)\end{array}$ & $\begin{array}{c}.745 \\
(.086)\end{array}$ & $\begin{array}{l}.143 \\
(.027)\end{array}$ & $\begin{array}{l}.132 \\
(.059)\end{array}$ & $\begin{array}{l}.236 \\
(.091)\end{array}$ & $\begin{array}{l}.219 \\
(.102)\end{array}$ & 665 & 104 \\
\hline 32 Radio, TV and Telecom & $\begin{array}{c}.905 \\
(.075)\end{array}$ & $\begin{array}{c}.894 \\
(.144)\end{array}$ & $\begin{array}{l}.068 \\
(.071)\end{array}$ & $\begin{array}{l}.064 \\
(.102)\end{array}$ & $\begin{array}{c}.204 \\
(.108)\end{array}$ & $\begin{array}{l}.151 \\
(.144)\end{array}$ & 302 & 54 \\
\hline 33 Medical Eq., Optical Instr. & $\begin{array}{c}.813 \\
(.074)\end{array}$ & $\begin{array}{c}.791 \\
(.147)\end{array}$ & $\begin{array}{c}.047 \\
(.054)\end{array}$ & $\begin{array}{c}.012 \\
(.080)\end{array}$ & $\begin{array}{c}.256 \\
(.101)\end{array}$ & $\begin{array}{l}.182 \\
(.131)\end{array}$ & 346 & 64 \\
\hline 34 Motor Vehicles & $\begin{array}{c}.843 \\
(.022)\end{array}$ & $\begin{array}{c}.776 \\
(.042)\end{array}$ & $\begin{array}{c}.108 \\
(.020)\end{array}$ & $\begin{array}{l}.120 \\
(.027)\end{array}$ & $\begin{array}{l}.050 \\
(.068)\end{array}$ & $\begin{array}{c}.087 \\
(.061)\end{array}$ & 752 & 121 \\
\hline 36 Furniture, Manuf. n.e.c. & $\begin{array}{c}.667 \\
(.039)\end{array}$ & $\begin{array}{c}.551 \\
(.086)\end{array}$ & $\begin{array}{l}.184 \\
(.025)\end{array}$ & $\begin{array}{l}.167 \\
(.055)\end{array}$ & $\begin{array}{l}.087 \\
(.057)\end{array}$ & $\begin{array}{l}.137 \\
(.063)\end{array}$ & 1,101 & 181 \\
\hline
\end{tabular}

Standard errors are computed using a block bootstrap procedure with 500 replications and are robust against heteroskedasticity and intra-group correlation 
Table 7: Results Productivity Services Sectors

\begin{tabular}{|c|c|c|c|c|c|c|c|c|}
\hline & \multicolumn{2}{|c|}{ Labor } & \multicolumn{2}{|c|}{ Capital } & \multicolumn{2}{|c|}{ Training } & \multicolumn{2}{|c|}{ Obs. } \\
\hline & OLS & $\mathrm{ACF}$ & OLS & $\mathrm{ACF}$ & OLS & $\mathrm{ACF}$ & Obs. & Clust. \\
\hline 1 Agriculture & $\begin{array}{c}.701 \\
(.058)\end{array}$ & $\begin{array}{c}.648 \\
(.077)\end{array}$ & $\begin{array}{c}.097 \\
(.035)\end{array}$ & $\begin{array}{c}.132 \\
(.074)\end{array}$ & $\begin{array}{c}.196 \\
(.164)\end{array}$ & $\begin{array}{c}.339 \\
(.134)\end{array}$ & 459 & 96 \\
\hline 14 Mining & $\begin{array}{c}.837 \\
(.059)\end{array}$ & $\begin{array}{l}.798 \\
(.250)\end{array}$ & $\begin{array}{l}.198 \\
(.056)\end{array}$ & $\begin{array}{c}.267 \\
(.305)\end{array}$ & $\begin{array}{c}.324 \\
(.120)\end{array}$ & $\begin{array}{c}.017 \\
(.143)\end{array}$ & 345 & 60 \\
\hline 37 Recycling & $\begin{array}{l}.737 \\
(.071)\end{array}$ & $\begin{array}{c}.737 \\
(.108)\end{array}$ & $\begin{array}{l}.164 \\
(.032)\end{array}$ & $\begin{array}{l}.124 \\
(.067)\end{array}$ & $\begin{array}{l}.239 \\
(.135)\end{array}$ & $\begin{array}{l}.242 \\
(.194)\end{array}$ & 364 & 79 \\
\hline 45 Construction & $\begin{array}{l}.774 \\
(.016)\end{array}$ & $\begin{array}{l}.773 \\
(.038)\end{array}$ & $\begin{array}{l}.136 \\
(.010)\end{array}$ & $\begin{array}{l}.134 \\
(.017)\end{array}$ & $\begin{array}{l}.184 \\
(.022)\end{array}$ & $\begin{array}{l}.123 \\
(.023)\end{array}$ & 5,521 & 939 \\
\hline 50 Sales Motor Vehicles & $\begin{array}{c}.804 \\
(.019)\end{array}$ & $\begin{array}{c}.803 \\
(.052)\end{array}$ & $\begin{array}{c}.091 \\
(.013)\end{array}$ & $\begin{array}{c}.081 \\
(.026)\end{array}$ & $\begin{array}{l}.295 \\
(.042)\end{array}$ & $\begin{array}{l}.179 \\
(.033)\end{array}$ & 3,974 & 746 \\
\hline 51 Wholesale Trade & $\begin{array}{c}.742 \\
(.008)\end{array}$ & $\begin{array}{l}.758 \\
(.013)\end{array}$ & $\begin{array}{c}.077 \\
(.005)\end{array}$ & $\begin{array}{c}.061 \\
(.006)\end{array}$ & $\begin{array}{c}.351 \\
(.021)\end{array}$ & $\begin{array}{c}.317 \\
(.022)\end{array}$ & 21,380 & 4,017 \\
\hline 52 Retail Trade & $\begin{array}{l}.779 \\
(.017)\end{array}$ & $\begin{array}{l}.735 \\
(.054)\end{array}$ & $\begin{array}{l}.158 \\
(.012)\end{array}$ & $\begin{array}{l}.158 \\
(.029)\end{array}$ & $\begin{array}{l}.125 \\
(.030)\end{array}$ & $\begin{array}{l}.135 \\
(.040)\end{array}$ & 4,104 & 869 \\
\hline 55 Hotels and Restaurants & $\begin{array}{c}.820 \\
(.030)\end{array}$ & $\begin{array}{l}.798 \\
(.058)\end{array}$ & $\begin{array}{l}.123 \\
(.022)\end{array}$ & $\begin{array}{l}.124 \\
(.047)\end{array}$ & $\begin{array}{l}.107 \\
(.043)\end{array}$ & $\begin{array}{c}.084 \\
(.047)\end{array}$ & 877 & 164 \\
\hline 60 Land Transport & $\begin{array}{l}.753 \\
(.021)\end{array}$ & $\begin{array}{l}.726 \\
(.070)\end{array}$ & $\begin{array}{l}.144 \\
(.015)\end{array}$ & $\begin{array}{l}.147 \\
(.043)\end{array}$ & $\begin{array}{l}.116 \\
(.060)\end{array}$ & $\begin{array}{c}.079 \\
(.043)\end{array}$ & 2,617 & 455 \\
\hline 63 Transport Activities & $\begin{array}{c}.633 \\
(.023)\end{array}$ & $\begin{array}{c}.681 \\
(.029)\end{array}$ & $\begin{array}{l}.174 \\
(.015)\end{array}$ & $\begin{array}{l}.133 \\
(.022)\end{array}$ & $\begin{array}{l}.305 \\
(.052)\end{array}$ & $\begin{array}{l}.222 \\
(.051)\end{array}$ & 1,892 & 411 \\
\hline 64 Post and Telecommunications & $\begin{array}{l}.753 \\
(.049)\end{array}$ & $\begin{array}{l}.749 \\
(.120)\end{array}$ & $\begin{array}{l}.202 \\
(.031)\end{array}$ & $\begin{array}{l}.175 \\
(.058)\end{array}$ & $\begin{array}{l}.283 \\
(.175)\end{array}$ & $\begin{array}{l}.284 \\
(.161)\end{array}$ & 337 & 86 \\
\hline 65 Financial Intermediation & $\begin{array}{c}.778 \\
(.072)\end{array}$ & $\begin{array}{c}.766 \\
(.189)\end{array}$ & $\begin{array}{l}.180 \\
(.048)\end{array}$ & $\begin{array}{l}.214 \\
(.123)\end{array}$ & $\begin{array}{c}.560 \\
(.264)\end{array}$ & $\begin{array}{c}.453 \\
(.209)\end{array}$ & 315 & 79 \\
\hline 70 Real Estate & $\begin{array}{c}.551 \\
(.028)\end{array}$ & $\begin{array}{c}.523 \\
(.048)\end{array}$ & $\begin{array}{l}.154 \\
(.020)\end{array}$ & $\begin{array}{c}.090 \\
(.040)\end{array}$ & $\begin{array}{c}.352 \\
(.091)\end{array}$ & $\begin{array}{c}.252 \\
(.114)\end{array}$ & 1,360 & 275 \\
\hline 71 Renting of Machinery & $\begin{array}{c}.507 \\
(.050)\end{array}$ & $\begin{array}{l}.575 \\
(.127)\end{array}$ & $\begin{array}{c}.367 \\
(.051)\end{array}$ & $\begin{array}{l}.300 \\
(.060)\end{array}$ & $\begin{array}{l}.104 \\
(.125)\end{array}$ & $\begin{array}{l}.149 \\
(.090)\end{array}$ & 487 & 96 \\
\hline 72 Computer and Related Activities & $\begin{array}{l}.855 \\
(.020)\end{array}$ & $\begin{array}{l}.849 \\
(.026)\end{array}$ & $\begin{array}{c}.084 \\
(.010)\end{array}$ & $\begin{array}{c}.088 \\
(.014)\end{array}$ & $\begin{array}{l}-.030 \\
(.039)\end{array}$ & $\begin{array}{c}.002 \\
(.046)\end{array}$ & 1,587 & 393 \\
\hline 74 Other Business Activities & $\begin{array}{c}.777 \\
(.014)\end{array}$ & $\begin{array}{c}.774 \\
(.028)\end{array}$ & $\begin{array}{l}.109 \\
(.009)\end{array}$ & $\begin{array}{c}.093 \\
(.015)\end{array}$ & $\begin{array}{l}.196 \\
(.031)\end{array}$ & $\begin{array}{c}.201 \\
(.038)\end{array}$ & 4,313 & 975 \\
\hline
\end{tabular}

Standard errors are computed using a block bootstrap procedure with 500 replications and are robust against heteroskedasticity and intra-group correlation 
Table 8: Results Wages Manufacturing Sectors

\begin{tabular}{|c|c|c|c|c|c|}
\hline & \multicolumn{3}{|c|}{ Training } & \multicolumn{2}{|c|}{ Nr. Obs. } \\
\hline & OLS1 & OLS2 & OLS3 & Obs. & Clust \\
\hline 15 Food Products & $\begin{array}{c}.353 \\
(.021)\end{array}$ & $\begin{array}{l}.155 \\
(.019)\end{array}$ & $\begin{array}{c}.121 \\
(.023)\end{array}$ & 21,447 & 3,259 \\
\hline 17 Textile Products & $\begin{array}{c}.296 \\
(.030)\end{array}$ & $\begin{array}{l}.171 \\
(.031)\end{array}$ & $\begin{array}{l}.118 \\
(.040)\end{array}$ & 7,311 & 1,068 \\
\hline 18 Wearing Apparel & $\begin{array}{c}.702 \\
(.190)\end{array}$ & $\begin{array}{l}.123 \\
(.224)\end{array}$ & $\begin{array}{c}.044 \\
(.189)\end{array}$ & 3,446 & 535 \\
\hline 20 Wood Products & $\begin{array}{c}.290 \\
(.073)\end{array}$ & $\begin{array}{l}.185 \\
(.048)\end{array}$ & $\begin{array}{l}.112 \\
(.054)\end{array}$ & 5,466 & 787 \\
\hline 21 Paper Products & $\begin{array}{c}.372 \\
(.044)\end{array}$ & $\begin{array}{l}.179 \\
(.036)\end{array}$ & $\begin{array}{l}.142 \\
(.041)\end{array}$ & 2,274 & 300 \\
\hline 22 Publishing & $\begin{array}{l}.364 \\
(.030)\end{array}$ & $\begin{array}{l}.074 \\
(.026)\end{array}$ & $\begin{array}{l}.078 \\
(.029)\end{array}$ & 14,398 & 2,322 \\
\hline 24 Chemical Products & $\begin{array}{l}.455 \\
(.103)\end{array}$ & $\begin{array}{c}.312 \\
(.032)\end{array}$ & $\begin{array}{c}.242 \\
(.043)\end{array}$ & 4,774 & 671 \\
\hline 25 Rubber and Plastic & $\begin{array}{l}.413 \\
(.031)\end{array}$ & $\begin{array}{c}.239 \\
(.025)\end{array}$ & $\begin{array}{l}.212 \\
(.042)\end{array}$ & 5,027 & 673 \\
\hline 26 Mineral Products & $\begin{array}{c}.306 \\
(.028)\end{array}$ & $\begin{array}{l}.155 \\
(.025)\end{array}$ & $\begin{array}{l}.143 \\
(.028)\end{array}$ & 7,680 & 1,062 \\
\hline 27 Basic Metals & $\begin{array}{c}.331 \\
(.053)\end{array}$ & $\begin{array}{l}.146 \\
(.048)\end{array}$ & $\begin{array}{l}.112 \\
(.048)\end{array}$ & 2,627 & 344 \\
\hline 28 Metal Products & $\begin{array}{l}.309 \\
(.020)\end{array}$ & $\begin{array}{l}.195 \\
(.031)\end{array}$ & $\begin{array}{l}.157 \\
(.031)\end{array}$ & 22,864 & 3,340 \\
\hline 29 Machinery & $\begin{array}{l}.429 \\
(.033)\end{array}$ & $\begin{array}{l}.237 \\
(.031)\end{array}$ & $\begin{array}{c}.197 \\
(.038)\end{array}$ & 8,253 & 1,228 \\
\hline 31 Electrical Machinery & $\begin{array}{l}.342 \\
(.041)\end{array}$ & $\begin{array}{l}.218 \\
(.049)\end{array}$ & $\begin{array}{l}.173 \\
(.057)\end{array}$ & 2,743 & 408 \\
\hline 32 Radio, TV and Telecom & $\begin{array}{l}.405 \\
(.078)\end{array}$ & $\begin{array}{l}.287 \\
(.059)\end{array}$ & $\begin{array}{l}.248 \\
(.080)\end{array}$ & 799 & 128 \\
\hline 33 Medical Eq., Optical Instr. & $\begin{array}{l}.359 \\
(.058)\end{array}$ & $\begin{array}{l}.104 \\
(.045)\end{array}$ & $\begin{array}{l}.073 \\
(.054)\end{array}$ & 3,079 & 475 \\
\hline 34 Motor Vehicles & $\begin{array}{l}.264 \\
(.046)\end{array}$ & $\begin{array}{l}.123 \\
(.045)\end{array}$ & $\begin{array}{l}.107 \\
(.047)\end{array}$ & 2,536 & 367 \\
\hline 36 Furniture, Manuf. n.e.c. & $\begin{array}{c}.305 \\
(.058)\end{array}$ & $\begin{array}{l}.177 \\
(.050)\end{array}$ & $\begin{array}{l}.143 \\
(.056)\end{array}$ & 9,591 & 1,442 \\
\hline
\end{tabular}

Standard errors are computed using a block bootstrap procedure with 500 replications and are robust against heteroskedasticity and intra-group correlation. The number of observations refers to the first specification where all firms are included. The number of observations used in the restricted sample of Columns (2) and (3) are equal to those reported in Table 7 
Table 9: Results Wages Services Sectors

\begin{tabular}{|c|c|c|c|c|c|}
\hline & \multicolumn{3}{|c|}{ Training } & \multicolumn{2}{|c|}{ Nr. Obs } \\
\hline & OLS1 & OLS2 & OLS3 & Obs. & Clust \\
\hline 1 Agriculture & $\begin{array}{l}.428 \\
(.058)\end{array}$ & $\begin{array}{l}.125 \\
(.090)\end{array}$ & $\begin{array}{c}.145 \\
(.074)\end{array}$ & 14,077 & 2,424 \\
\hline 14 Mining & $\begin{array}{l}.329 \\
(.083)\end{array}$ & $\begin{array}{l}.091 \\
(.069)\end{array}$ & $\begin{array}{l}.050 \\
(.073)\end{array}$ & 1,126 & 157 \\
\hline 37 Recycling & $\begin{array}{l}.305 \\
(.074)\end{array}$ & $\begin{array}{l}.267 \\
(.096)\end{array}$ & $\begin{array}{l}.254 \\
(.095)\end{array}$ & 1,668 & 274 \\
\hline 45 Construction & $\begin{array}{l}.335 \\
(.014)\end{array}$ & $\begin{array}{l}.150 \\
(.018)\end{array}$ & $\begin{array}{l}.134 \\
(.019)\end{array}$ & 133,695 & 21,316 \\
\hline 50 Sales Motor Vehicles & $\begin{array}{l}.375 \\
(.021)\end{array}$ & $\begin{array}{l}.185 \\
(.024)\end{array}$ & $\begin{array}{l}.137 \\
(.027)\end{array}$ & 48,134 & 7,519 \\
\hline 51 Wholesale Trade & $\begin{array}{l}.468 \\
(.014)\end{array}$ & $\begin{array}{l}.191 \\
(.013)\end{array}$ & $\begin{array}{l}.181 \\
(.014)\end{array}$ & 120,834 & 19,621 \\
\hline 52 Retail Trade & $\begin{array}{l}.254 \\
(.020)\end{array}$ & $\begin{array}{l}.078 \\
(.020)\end{array}$ & $\begin{array}{l}.060 \\
(.025)\end{array}$ & 110,918 & 19,138 \\
\hline 55 Hotels and Restaurants & $\begin{array}{l}.326 \\
(.032)\end{array}$ & $\begin{array}{l}.122 \\
(.031)\end{array}$ & $\begin{array}{l}.104 \\
(.034)\end{array}$ & 54,774 & 10,545 \\
\hline 60 Land Transport & $\begin{array}{l}.195 \\
(.022)\end{array}$ & $\begin{array}{l}.094 \\
(.029)\end{array}$ & $\begin{array}{l}.061 \\
(.028)\end{array}$ & 35,808 & 5,451 \\
\hline 63 Transport Activities & $\begin{array}{l}.175 \\
(.026)\end{array}$ & $\begin{array}{l}.121 \\
(.032)\end{array}$ & $\begin{array}{l}.100 \\
(.034)\end{array}$ & 14,923 & 2,450 \\
\hline 64 Post and Telecommunications & $\begin{array}{l}.409 \\
(.067)\end{array}$ & $\begin{array}{l}-.014 \\
(.105)\end{array}$ & $\begin{array}{l}-.082 \\
(.106)\end{array}$ & 2,869 & 650 \\
\hline 65 Financial Intermediation & $\begin{array}{c}.401 \\
(.052)\end{array}$ & $\begin{array}{l}.025 \\
(.107)\end{array}$ & $\begin{array}{l}-.021 \\
(.115)\end{array}$ & 10,220 & 1,928 \\
\hline 70 Real Estate & $\begin{array}{l}.542 \\
(.042)\end{array}$ & $\begin{array}{l}.303 \\
(.064)\end{array}$ & $\begin{array}{l}.265 \\
(.072)\end{array}$ & 20,425 & 4,013 \\
\hline 71 Renting of Machinery & $\begin{array}{l}.547 \\
(.040)\end{array}$ & $\begin{array}{l}.129 \\
(.059)\end{array}$ & $\begin{array}{l}.084 \\
(.051)\end{array}$ & 4,971 & 905 \\
\hline 72 Computer and Related Activities & $\begin{array}{l}.316 \\
(.021)\end{array}$ & $\begin{array}{l}-.024 \\
(.031)\end{array}$ & $\begin{array}{l}-.005 \\
(.037)\end{array}$ & 15,837 & 3,281 \\
\hline 74 Other Business Activities & $\begin{array}{l}.409 \\
(.012)\end{array}$ & $\begin{array}{l}.143 \\
(.021)\end{array}$ & $\begin{array}{l}.137 \\
(.024)\end{array}$ & 90,400 & 17,081 \\
\hline
\end{tabular}

Standard errors are computed using a block bootstrap procedure with 500

replications and are robust against heteroskedasticity and intra-group correlation.

The number of observations refers to the first specification where all firms are

included. The number of observations used in the restricted sample of Columns

(2) and (3) are equal to those reported in Table 7 
Table 10: Training as Average Training Costs per Trained Worker

\begin{tabular}{|c|c|c|c|c|c|c|c|c|}
\hline & \multicolumn{2}{|c|}{ Total } & \multicolumn{2}{|c|}{ Manufacturing } & \multicolumn{2}{|c|}{ Services } & \multirow{2}{*}{\multicolumn{2}{|c|}{ Each Sector Seperat. }} \\
\hline & Prod. & Wage & Prod. & Wage & Prod. & Wage. & & \\
\hline \multirow[t]{2}{*}{ Capital } & .092 & & .130 & & .085 & & $\beta_{T}$ & \\
\hline & $(.004)$ & & $(.024)$ & & $(.004)$ & & Min & .012 \\
\hline \multirow[t]{2}{*}{ Labor } & .771 & & .799 & & .759 & & Max & .201 \\
\hline & $(.007)$ & & $(.082)$ & & $(.009)$ & & Av. & .103 \\
\hline \multirow[t]{2}{*}{ Training } & .107 & .090 & .094 & .097 & .113 & .090 & & \\
\hline & $(.006)$ & $(.004)$ & $(.010)$ & $(.007)$ & $(.008)$ & $(.005)$ & $\alpha_{T}$ & \\
\hline \multirow[t]{2}{*}{ TFP } & & .339 & & .306 & & .347 & Min & .024 \\
\hline & & $(.006)$ & & $(.036)$ & & $(.007)$ & Max & .145 \\
\hline \multirow[t]{2}{*}{ Cap/Lab } & & -.014 & & .017 & & -.021 & Av. & .083 \\
\hline & & $(.002)$ & & $(.004)$ & & $(.002)$ & & \\
\hline \multirow{2}{*}{$\begin{array}{l}\text { Test for } \beta_{T}=\alpha_{T} \\
C h i^{2}\end{array}$} & \multirow{2}{*}{\multicolumn{2}{|c|}{51.2}} & \multirow{2}{*}{\multicolumn{2}{|c|}{1.62}} & \multirow{2}{*}{\multicolumn{2}{|c|}{46.3}} & & \\
\hline & & & & & & & & \\
\hline$p-$ value & \multicolumn{2}{|c|}{.00} & \multicolumn{2}{|c|}{.20} & \multicolumn{2}{|c|}{.00} & & \\
\hline
\end{tabular}

Standard errors are computed using a block bootstrap procedure with 500 replications and are robust against heteroskedasticity and intra-group correlation

Table 11: Results Further Robustness Checks

\begin{tabular}{lcccccc}
\hline \hline & \multicolumn{3}{c}{ Total } & \multicolumn{2}{c}{ Manufacturing } & \multicolumn{2}{c}{ Services } \\
& Prod. & Wage & Prod. & Wage & Prod. & Wage \\
\hline Non-Linear Specification & .374 & .233 & .313 & .259 & .407 & .239 \\
SUR Model & .295 & .208 & .310 & .225 & .273 & .199 \\
& $(.006)$ & $(.005)$ & $(.009)$ & $(.007)$ & $(.008)$ & $(.006)$ \\
Wage as Control & .189 & .168 & .201 & .178 & .171 & .160 \\
& $(.010)$ & $(.006)$ & $(.018)$ & $(.009)$ & $(.013)$ & $(.008)$ \\
\hline \hline
\end{tabular}

replications and are robust against heteroskedasticity and intra-group correlation

Table 12: Disitinction between Male and Female Trained Workers

\begin{tabular}{lcccccc}
\hline \hline & \multicolumn{2}{c}{ Total } & \multicolumn{2}{c}{ Manufacturing } & \multicolumn{2}{c}{ Services } \\
& Prod. & Wage & Prod. & Wage & Prod. & Wage. \\
\hline$\beta_{k}$ & .103 & & .131 & & .097 & \\
$\beta_{l}$ & & & $(.059)$ & & $(.010)$ & \\
& .736 & & .764 & & .723 & \\
$\phi_{T}$ or $\lambda_{T}$ & .328 & .147 & .245 & .158 & .369 & .146 \\
$\phi_{F}$ or $\lambda_{F}$ & $(.023)$ & $(.012)$ & $. .081)$ & $(.035)$ & $(.031)$ & $(.015)$ \\
& .016 & -.163 & -.074 & -.230 & .044 & -.138 \\
$\phi_{F \times T}$ or $\lambda_{F \times T}$ & $.042)$ & $(.016)$ & $(.568)$ & $(.037)$ & $(.049)$ & $(.019)$ \\
& $(.063)$ & .201 & .306 & .258 & .081 & .194 \\
\hline \hline
\end{tabular}

Productivity estimates refer to estimation of Equation (A.4) and are controlled for simultaneity bias (ACF procedure).Wage results refer to estimation of Equation (A.10) by nonlinear least squares with added control variables.

Standard errors are computed using a block bootstrap procedure with 500 replications and are robust against heteroskedasticity and intra-group correlation 
Table 13: Worker Heterogeneity

\begin{tabular}{lcccccc}
\hline \hline & \multicolumn{2}{c}{ Total } & \multicolumn{2}{c}{ Manufacturing } & \multicolumn{2}{c}{ Services } \\
& Prod. & Wage & Prod. & Wage & Prod. & Wage. \\
\hline Type of Contract $\left(\beta_{l} \phi_{T}\right.$ or $\left.\lambda_{T}\right)$ & .176 & .141 & .173 & .174 & .180 & .122 \\
Schooling $\left(\beta_{l} \phi_{T}\right.$ or $\left.\lambda_{T}\right)$ & $(.010)$ & $(.006)$ & $(.015)$ & $(.008)$ & $(.013)$ & $(.008)$ \\
& .152 & .090 & .155 & .128 & .149 & .076 \\
& $(.010)$ & $(.009)$ & $(.015)$ & $(.010)$ & $(.013)$ & $(.008)$ \\
\hline \hline
\end{tabular}

Productivity estimates refer to estimation of Equations (A.7) and (A.8) and are controlled for simultaneity bias (ACF procedure).Wage results refer to estimation of Equations (A.13) and (A.14) by ordinary least squares with added control variables. Standard errors are computed using a block bootstrap procedure 500 replications and are robust against heteroskedasticity and intra-group correlation 
Figure 1: Impact Training on Productivity and Wages Impact Training on Wages and Productivity

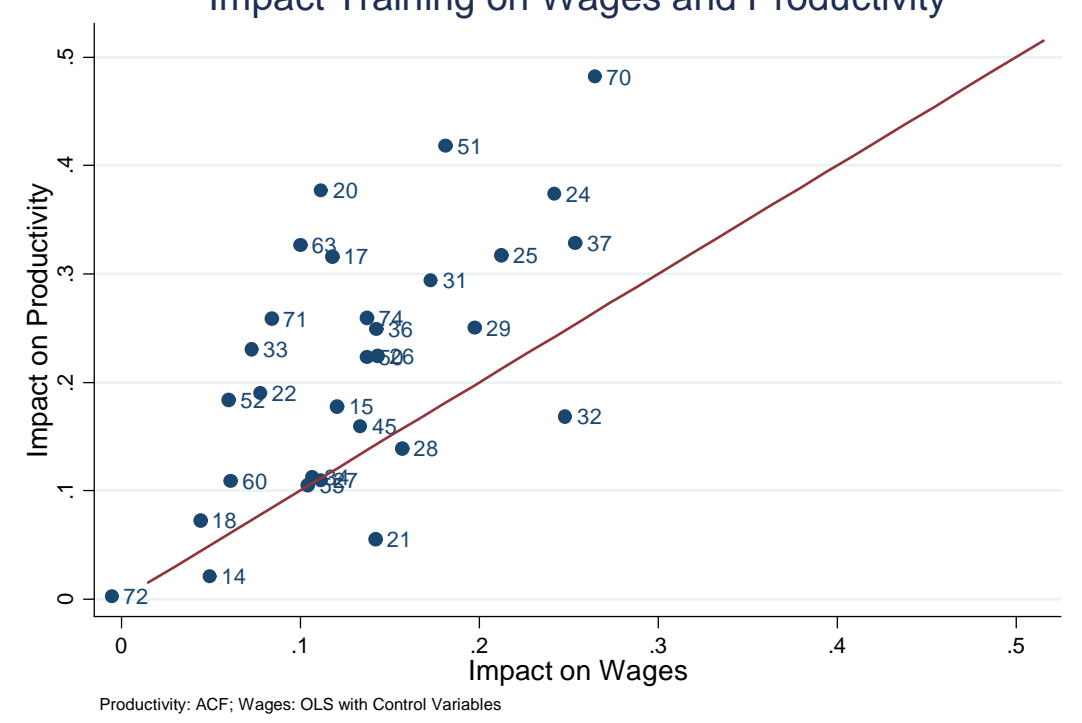


Figure 2: Impact Training on Productivity and Wages, Training as Continuous Variable

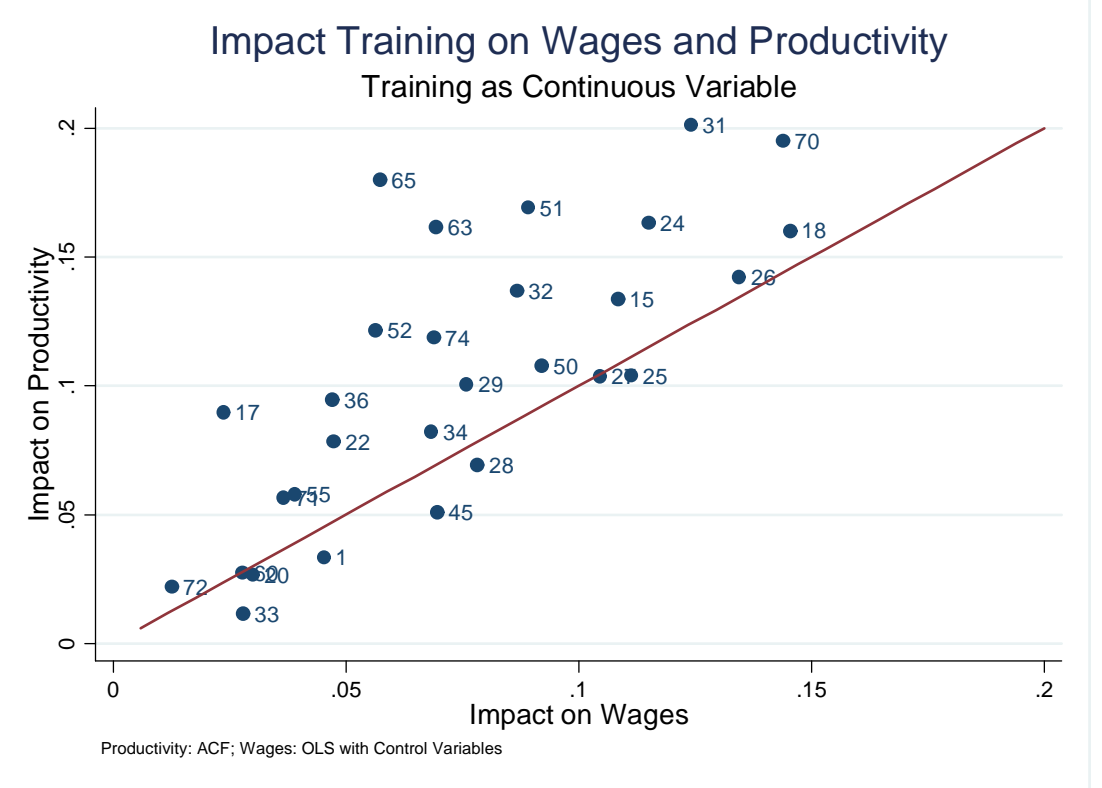




\section{Appendix}

\section{A Other sources of worker heterogeneity}

\section{A.1 Productivity}

The derivations in the main text assumed that training is the only source of heterogeneity in the labor force. This appendix shows how we can generalize the expression for the labor aggregate when workers can be differentiated by multiple characteristics. Next to training we also observe the gender of the labor force, whether the workers are blue collar, white collar or part of the management staff and their schooling level. When there are multiple observed characteristics, the workforce can be described by all $K$ possible combinations of these characteristics and the labor aggregate $\widehat{L}$ can be written as:

$$
\widehat{L}=L_{0}+\sum_{k=1}^{K-1}\left(1+\phi_{k}\right) L_{k}
$$

where again $\phi_{k}$ is the productivity premium of a type $k$ worker relative to a worker of the base type $\left(\phi_{k}=\frac{M P_{k}-M P_{0}}{M P_{0}}\right)$. When we include for example training and the type of contract (blue collar, white collar or management) as worker characteristics, there are six different types of workers namely untrained blue collar, untrained white collar, untrained management, trained blue collar, trained white collar and trained managament. If the base type is an untrained blue collar worker, then for example the relative productivity premium of a trained white collar worker, $\phi_{T W}$, is defined as $\phi_{k}=\frac{M P_{T W}-M P_{U B}}{M P_{U B}}$ with $M P_{T W}$ the marginal product of a trained white collar worker and $M P_{U B}$ the marginal product of an untrained blue collar worker. Again, the labor aggregate can be rewritten as:

$$
\widehat{L}=L\left(1+\sum_{k=1}^{K-1} \phi_{k} \frac{L_{k}}{L}\right)
$$

and note that to estimate the productivity premium of each different type of worker, we need to observe the proportion of each type in the total workforce. While we lack data on training differentiated by the employment contract of the trained worker, we do observe the gender of each trained employee. We divide the labor force into untrained male, untrained female, trained male and trained female workers. Consequently, the above equation can be redefined as

$$
\widehat{L}=L\left(1+\phi_{F} \frac{L_{F U}}{L}+\phi_{T} \frac{L_{M T}}{L}+\left[\left(1+\phi_{F}\right)\left(1+\phi_{T}\right)\left(1+\phi_{F \times T}\right)-1\right] \frac{L_{F T}}{L}\right)
$$

where $L_{M U}$ represents the number of male workers that did not receive training, which is the base category. $L_{F U}, L_{M T}$ and $L_{F T}$ are the number of untrained females, trained males and trained females respectively. The productivity premium for an untrained female worker $\phi_{F}$ is given by $\phi_{F} \equiv \frac{M P_{F U}-M P_{M U}}{M P_{M U}}$ and is defined relative to the productivity of an untrained male worker. Likewise, $\phi_{T}$ is the productivity premium of a trained male worker The productivity premium 
of a trained female worker can be decomposed into the product of female and training premia and an interaction between the two, namely $\phi_{F \times T}$. When this interaction is larger than zero, training of females pays off more than training of male workers and the other way around when the interaction is negative. A value of zero for this parameter means that marginal productivity increases by the same amount for female workers as for male workers. Like before, the expression for the labor aggregate can be plugged in in the production function and renders estimates for the differential impact of training on female compared to male workers:

$$
\begin{aligned}
y= & \beta_{0}+\beta_{k} k+\beta_{l} l+\beta_{l} \phi_{F U} \frac{L_{F U}}{L}+\beta_{l} \phi_{M T} \frac{L_{M T}}{L}+ \\
& \beta_{l}\left(\left(1+\phi_{T}\right)\left(1+\phi_{F}\right)\left(1+\phi_{F \times T}\right)-1\right) \frac{L_{F T}}{L}+\mu
\end{aligned}
$$

Unfortunately we do not observe the other worker characteristics for trained versus untrained workers which forces us to make some simplifying restrictions to retrieve an expression for the labor aggregate that can be estimated. These assumptions are similar to other studies that divide the labor force among several dimensions to reduce the number of parameter to be estimated (e.g. Van Biesebroeck, 2007). First, we have to assume that he relative differences in marginal productivity between two workers that differ by one characteristic are the same irrespective of what their other characteristics are. This means that the relative marginal product of trained workers compared to untrained workers is the same for all different types of workers. Furthermore we restrict the proportion of one type of workers to be constant across other groups defined by the other characteristics. We apply these restrictions to two different divisions of the labor force.

First we divide the workers among their type of job (blue collar, white collar or management) and training status. As a result, the unrestricted version of the labor aggregate would consist of six terms, one for each different type of worker. Applying the restrictions, simplifies the expression for the labor aggregate considerably and is given by

$$
\widehat{L}=L\left(1+\phi_{Z} \frac{L_{Z}}{L}+\phi_{W} \frac{L_{W}}{L}\right)\left(1+\phi_{T} \frac{L_{T}}{L}\right)
$$

where $L_{Z}$ and $L_{W}$ represent management and white colar workers respectively. $\phi_{Z}$ and $\phi_{W}$ represent the productivity premium of a manager and white collar worker respectively relative to the productivity of a blue collar worker. These relative productivity premiums are the same irrespective of the training status of the worker.

Second, we divide the labor force among the schooling level and training status of the workers. Schooling is constructed such that the variable takes on two values, namely high-schooled and low-schooled. The restricted version of the labor aggregate can be written as

$$
\widehat{L}=L\left(1+\phi_{S} \frac{L_{S}}{L}\right)\left(1+\phi_{T} \frac{L_{T}}{L}\right)
$$

where $L_{S}$ is the number of high schooled workers and $\phi_{S}$ represents the productivity premium of a high-schooled worker relative to a low-schooled worker. The 
production function equations that are taken to the data are then reespectively:

$$
y=\beta_{0}+\beta_{k} k+\beta_{l} l+\beta_{l} \phi_{T} \frac{L_{T}}{L}+\beta_{l} \phi_{W} \frac{L_{W}}{L}+\beta_{l} \phi_{Z} \frac{L_{Z}}{L}+\mu
$$

and

$$
y=\beta_{0}+\beta_{k} k+\beta_{l} l+\beta_{l} \phi_{T} \frac{L_{T}}{L}+\beta_{l} \phi_{S} \frac{L_{S}}{L}+\mu
$$

\section{A.2 Wages}

In a similar way, we can extend the empirical framework for estimating wage premia by including multiple characteristics of the workforce. Similar to the production function, we want to measure the differential impact of training on wages for male and female workers. Dividing the labor force into four types, namely male untrained, male trained, female untrained and female trained, we can write the average wage in a firm as

$\bar{W}=W_{M U}\left(1+\lambda_{T} \frac{L_{M T}}{L}+\lambda_{F} \frac{L_{F U}}{L}+\left[\left(1+\lambda_{T}\right)\left(1+\lambda_{F}\right)\left(1+\lambda_{F \times T}\right)-1\right] \frac{L_{F T}}{L}\right)$

whith $W_{F U}$ the wage of an untrained female worker and $W_{M U}$ the wage of an untrained male worker. The wage premium of a female worker $\lambda_{F}$ is defined as $\lambda_{F}=\frac{W_{F U}-W_{M U}}{W_{M U}}$. Likewise the wage premium for a male trained worker $\lambda_{T}$ is defined relative to the wage of an untrained male worker. The coefficient $\lambda_{F \times T}$ for the interaction between being female and trained is equal to zero if the wage premium for a trained worker is the same for males and females. Taking natural logarithms and adding control variables and an additive error term, the equation that is estimated is:

$\bar{w}=w_{B U}+\lambda_{F} \frac{L_{U F}}{L}+\lambda_{T} \frac{L_{T}}{L}+\left(\left(1+\lambda_{F}\right)\left(1+\lambda_{T}\right)\left(1+\lambda_{F \times T}\right)-1\right) \frac{L_{T F}}{L}+X \gamma+\varepsilon$

We also include the schooling level and type of job (blue collar, white collar, management) as extra characteristics. We impose similar restrictions as for estimating the productivity premium, namely equal proportions and equal relative wage premia assumptions. Dividing the labor force among their type of job and training status and applying these restrections renders the following expression for the average wage, $\bar{W}$ in a firm:

$$
\bar{W}=W_{B U}\left(1+\lambda_{Z} \frac{L_{Z}}{L}+\lambda_{W} \frac{L_{W}}{L}\right)\left(1+\lambda_{T} \frac{L_{T}}{L}\right)
$$

where $W_{B U}$ is the wage of an untrained blue collar worker and $\lambda_{Z}$ and $\lambda_{W}$ are the relative wage premia of a manager and a white collar worker. Likewise, when dividing the labor force among the schooling level and training status, the expression for the average wage becomes:

$$
\bar{W}=W_{B U}\left(1+\lambda_{S} \frac{L_{S}}{L}\right)\left(1+\lambda_{T} \frac{L_{T}}{L}\right)
$$


where $\lambda_{S}$ represents the wage premium of a schooled worker. Taking natural logarithms and adding control variables and an additive error term, one obtains the equations that will be estimated:

$$
\bar{w}=w_{B U}+\lambda_{W} \frac{L_{W}}{L}+\lambda_{Z} \frac{L_{Z}}{L}+\lambda_{T} \frac{L_{T}}{L}+X \gamma+\varepsilon
$$

and

$$
\bar{w}=w_{L U}+\lambda_{S} \frac{L_{S}}{L}+\lambda_{T} \frac{L_{T}}{L}+X \gamma+\varepsilon
$$




\section{B Fixed Effects}

Table B.1: Fixed Effects Regression

\begin{tabular}{|c|c|c|c|c|c|c|c|c|}
\hline \multirow{3}{*}{ Capital } & \multicolumn{2}{|c|}{ Total } & \multicolumn{2}{|c|}{ Manufacturing } & \multicolumn{2}{|c|}{ Services } & \multirow{2}{*}{\multicolumn{2}{|c|}{$\begin{array}{l}\text { Each Sector } \\
\text { Separately }\end{array}$}} \\
\hline & \multirow{2}{*}{$\begin{array}{c}\text { Prod. } \\
.064 \\
(.002)\end{array}$} & \multirow[t]{2}{*}{ Wage } & \multirow{2}{*}{$\begin{array}{c}\text { Prod. } \\
.067 \\
(.003)\end{array}$} & \multirow[t]{2}{*}{ Wage } & \multirow{2}{*}{$\begin{array}{c}\text { Prod. } \\
.063 \\
(.002)\end{array}$} & \multirow[t]{2}{*}{ Wage. } & & \\
\hline & & & & & & & $\begin{array}{l}\phi_{T} \\
\text { Min }\end{array}$ & -.037 \\
\hline Labor & $\begin{array}{l}.668 \\
(.003)\end{array}$ & & $\begin{array}{l}.688 \\
(.006)\end{array}$ & & $\begin{array}{l}.661 \\
(.004)\end{array}$ & & $\begin{array}{l}\text { Max } \\
\text { Avg. }\end{array}$ & $\begin{array}{l}.36 \\
.096\end{array}$ \\
\hline Training & $\begin{array}{l}.044 \\
(.005)\end{array}$ & $\begin{array}{c}.025 \\
(.003)\end{array}$ & $\begin{array}{l}.048 \\
(.008)\end{array}$ & $\begin{array}{l}.031 \\
(.004)\end{array}$ & $\begin{array}{l}.042 \\
(.006)\end{array}$ & $\begin{array}{c}.023 \\
(.004)\end{array}$ & $\begin{array}{l}\lambda_{T} \\
\text { Min. }\end{array}$ & \\
\hline Cap/Lab & & $\begin{array}{l}.027 \\
(.001)\end{array}$ & & $\begin{array}{l}.028 \\
(.002)\end{array}$ & & $\begin{array}{l}.026 \\
(.001)\end{array}$ & $\begin{array}{l}\text { Max. } \\
\text { Max. } \\
\text { Avg. }\end{array}$ & $\begin{array}{l}-.044 \\
.104 \\
.026\end{array}$ \\
\hline $\begin{array}{l}\text { Nr. Obs. } \\
\text { Test for } \phi_{T}=\lambda_{T}\end{array}$ & 88,357 & 89,991 & 27,271 & 27,519 & 61,086 & 62,472 & & \\
\hline $\begin{array}{l}\text { Chi }{ }^{2} \\
p-\text { value }\end{array}$ & & & & & & & & \\
\hline
\end{tabular}


Figure B.1: Impact Training on Productivity and Wages: Fixed Effects.

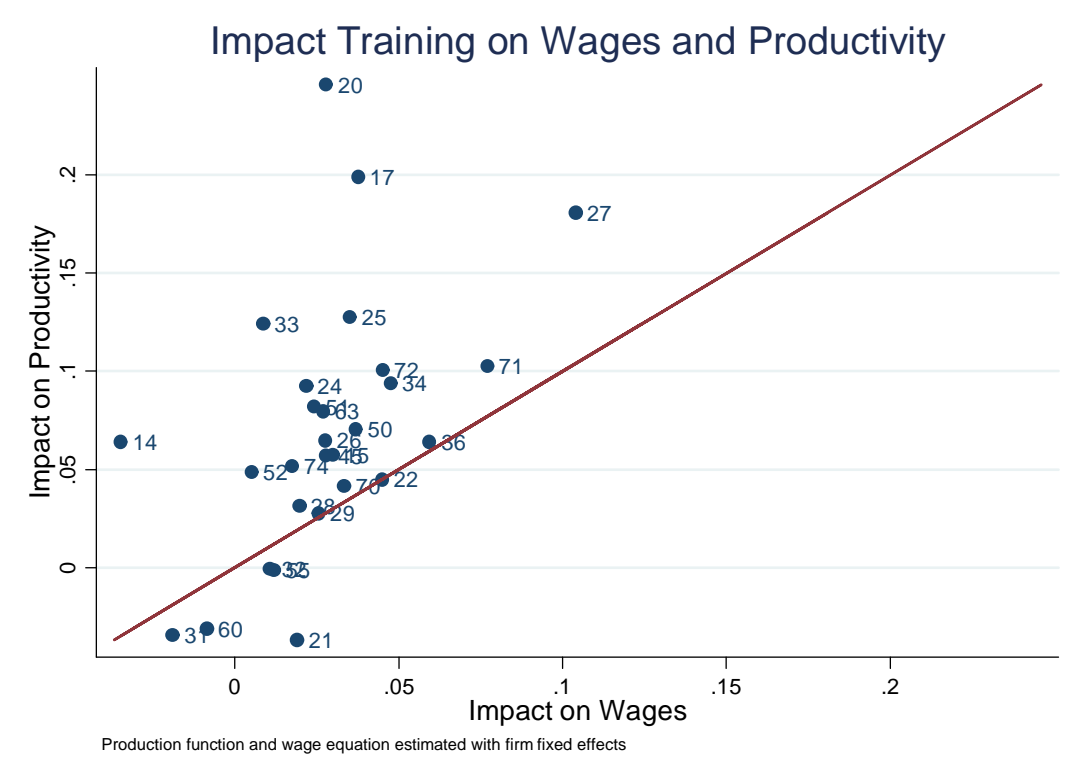




\section{Training and Seperation Rates}

Table C.1: Seperation rates and training

\begin{tabular}{lcccc}
\hline \hline & \multicolumn{2}{c}{ FE one lag } & \multicolumn{2}{c}{ FE 2 lags } \\
& Dismissals & Quits & Dismissals & Quits \\
\hline Train. Share $\mathrm{t}_{\mathrm{t}} 1$ & $-.00254^{*}$ & -.00132 & $-.0028^{*}$ & -.0023 \\
& $(.0015)$ & $(.0024)$ & $(.0015)$ & $(.00241)$ \\
& & & & \\
Train. Share ${ }_{\mathrm{t}-2}$ & & & .00174 & $.00627^{* *}$ \\
& & & $(.00149)$ & $(.00237)$ \\
\hline Nr. Obs & 76,359 & 76,359 & 76340 & 76340 \\
\hline \hline Firm and year fixed effects included & & \\
$* p<0.10,{ }^{* *} p<0.05$ & & &
\end{tabular}

